\title{
ALGUNAS CONDICIONES DE LEGITIMIDAD DEL PRINCIPIO DEL BIEN JURÍDICO PENALMENTE PROTEGIDO
}

\author{
Antonio Cardona Barber \\ Doctor en Derecho penal \\ Profesor e investigador contratado en la UAB
}

SUMARIO: I. Cuestiones introductorias. II. Funciones del principio del bien jurídico protegido. III. El alcance legítimo de protección jurídico-penal. 1. Los valores o intereses morales como límites de tutela penal. 2. ¿Bienes individuales o bienes colectivos? 3. El bien jurídico «penalmente» protegido y la cuestión de la intervención mínima penal. 4. ¿Son los sentimientos un objeto legítimo de protección penal? 5. La discusión sobre los derechos constitucionalmente reconocidos como límites de tutela penal. IV. El principio de proporcionalidad en relación al bien jurídico protegido. V. Conclusiones. Bibliografía.

Resumen: El Derecho penal sirve para proteger determinados bienes jurídicos, los más importantes para el individuo y la sociedad. Ahora bien, qué límites o márgenes deben exigirse para que los bienes jurídicos protegidos puedan ser considerados bienes jurídicos «legítimamente» protegidos es una pregunta que genera cierta discusión doctrinal. En este sentido, por medio de este artículo se intentará abordar esta cuestión.

Abstract: Criminal law serves to protect certain interests, the most important for the individual and society. However, what limits or margins must be demanded so that protected legal rights can be considered as "legally" protected legal interests is a question that generates a certain doctrinal discussion. In this sense, this article will attempt to address this issue through this article.

Palabras clave: Bien jurídico protegido. Límites de tutela jurídico-penal. Bienes individuales. Bienes colectivos. Intereses constitucionales. Sentimientos protegidos penalmente. 


\section{Cuestiones introductorias}

En la actualidad, la Doctrina mayoritaria afirma que el Derecho penal es un medio de control social formalizado e institucionalizado que sirve para prevenir los ataques más graves a los bienes jurídicos más importantes ${ }^{1}$.

En este sentido, el libre desarrollo de la personalidad en sociedad precisa de una serie de presupuestos que pueden conceptualizarse como bienes, y, en tanto que éstos sean reconocidos y tutelados por el ordenamiento jurídico, serán bienes jurídicos.

No obstante, qué intereses o valores concretos deben elevarse a la categoría de bienes jurídicos y, con ello, gozar de protección penal, nunca ha sido una cuestión fácil de resolver. Todavía hoy no se ha alcanzado un acuerdo doctrinal pacífico a la hora de definir los límites materiales de este principio, y, por ello, esta cuestión constituye una de las principales contingencias a la que debe enfrentarse la teoría del bien jurídico protegido $^{2}$. En este contexto, no puede desconocerse que los mismos autores que defienden la importancia y relevancia práctica del principio del bien jurídico protegido ${ }^{3}$, reconocen, a su vez, que para este principio se pueden dar una pluralidad de definiciones ${ }^{4}$.

1 Ahora bien, debemos tener presente que no todos los países de nuestro entorno cultural incorporan en su Derecho penal la teoría del bien jurídico protegido. En concreto, tal y como señala Claus Roxin, «el concepto de bien jurídico protegido es irrelevante, por ejemplo, en Francia o los EE.UU» ahora bien, el mismo autor nos avisa de que, «sin embargo, el penalista norteamericano DubBer subraya, al menos, que sería positivo que la doctrina, la legislación y la jurisprudencia en los Estados Unidos se refirieran a un concepto de bien jurídico sistemáticamente unitario» y que, "por otra parte, el harm principle desarrollado en el Derecho penal anglo-americano - esto es, la limitación de la sanción jurídico-penal a modalidades de comportamiento que generen un daño- es próximo al principio de protección de bienes jurídicos»: Roxin Claus, El concepto de bien jurídico como instrumento de crítica legislativa sometido a examen, Revista Electrónica de Ciencia Penal y Criminología, ISSN 1695-0194, 2013.

2 Por ejemplo, Roxin asegura que «de qué sea un bien jurídico hay tantas y tan distintas opiniones que solo se puede discutir con sentido sobre este tema si previamente se aclara qué es lo que uno mismo entiende por bien jurídico y de dónde infiere la limitación del Derecho penal a la protección de bienes jurídicos»: Roxin, Claus, "¿Es la protección de bienes jurídicos una finalidad del Derecho penal?», en Roland HeFENDEHL (ed.) La teoría del bien jurídico, ¿Fundamentos de legitimación del derecho penal o juego de abalorios dogmático?, Madrid, Marcial Pons, 2007.

3 Por ejemplo Hassemer señala que: «La necesidad de un bien jurídico penal como fundamento legitimador de una conminación penal no se puede poner seriamente en duda»: HAsSEMER, W; ¿Puede haber delitos que no afecten a un bien jurídico penal? en «La teoría del bien jurídico ¿Fundamentos de legitimación del Derecho penal o juego de abalorios dogmático?» Barcelona, Marcial Pons, 2007, p. 104.

4 Gimbernat Ordeig, E, «Presentación», en Roland Hefendehl (ed.), La teoría del bien jurídico, ¿Fundamento de legitimación del Derecho penal o juego de abalorios dogmático?, Madrid, Marcial Pons, 2007, p.11. Reconociendo este mismo autor que incluso, y de for- 
Pues bien, de entrada, quiero señalar que acojo una visión iuspositivista del ordenamiento jurídico, y, por ello, considero que todos los Derechos, también los fundamentales, nacen del acuerdo político-legislativo, alejándome, por tanto, de visiones iusnaturalistas que deducen un supuesto Derecho prexistente por medio de la razón humana. En coherencia, entiendo que los bienes jurídicos protegidos son hijos de su tiempo y circunstancias, y, por ello, no son conceptos universales cuya legitimidad pueda deducirse con metodologías apriorísticas.

Así, desde un punto de vista «formal», un bien jurídico protegido es un instrumento creado por el Derecho. Es decir, un determinado valor o interés formalmente tendrá la consideración de bien jurídico protegido en tanto que su tutela y protección esté encomendada al ordenamiento jurídico $^{5}$. Más difícil será poder concretar el grado de «legitimidad material» del interés penalmente tutelado, cuestión que trataré de abordar a lo largo del presente artículo.

\section{Funciones del principio del bien jurídico protegido}

Si bien el objeto del presente artículo pasa por tratar algunas de las condiciones de legitimidad del principio del bien jurídico protegido, considero que en la actualidad es muy necesario reivindicar la utilidad práctica de éste principio, y, por ello, utilizo este apartado para tal cuestión. De hecho, no puede desconocerse que en los últimos años la importancia del principio del bien jurídico protegido ha sido cuestionada (a mi juicio equivocadamente) por algunos autores, los cuales, «niegan, en mayor o menor medida, que la finalidad del Derecho penal sea la de proteger bienes jurídicos, manteniendo JAKOBS y su escuela, por ejemplo, que esa finalidad consistiría en la protección de la vigencia de la norma ${ }^{6}$.

En este sentido, el concepto del bien jurídico tiene dos caracteres funcionales diferenciados: puede utilizarse tanto desde un punto de vista dogmático como desde un punto de vista de política criminal. En el primer escenario el bien jurídico se identifica con el interés concretamente protegido por el Derecho, facilitando con ello las funciones exegéticas judiciales en la interpretación de la norma y la subsunción (o no) del caso concretamente enjuiciado. En el escenario de política criminal el bien jurídico sirve para elegir qué intereses o valores concretos deben (o

ma excepcional, «en algunos tipos penales es difícil determinar qué bien jurídico estarían tutelando".

5 Von Liszt, F, Tratado de Derecho Penal, Tomo II, traducido por Jiménez DE AsúA, Madrid, 1916, p.6

6 Gimbernat Ordeig, E, «Presentación», en Roland Hefendehl (ed.), La teoría del bien jurídico... Ob. cit., p. 11. 
deberían) ser protegidos jurídicamente, orientando con ello las tareas del legislador penal ${ }^{7}$.

(a) La función interpretativa o dogmática

Actualmente, el principio del bien jurídico protegido tiene un peso muy significativo en el campo operativo judicial, al constituir éste un instrumento esencial para interpretar los tipos penales y, con ello, constituye «una garantía fundamental del Derecho penal moderno ${ }^{8}$. De hecho, considero que la función principal del bien jurídico protegido es esta función dogmática. En concreto, gracias al principio de exclusiva protección de bienes jurídicos pueden llevarse a cabo interpretaciones restrictivas, garantistas y racionales, de los tipos penales, evitándose con ello subsunciones que no cupieran teleológicamente en el marco de protección de la norma ${ }^{9}$.

Es más, no toda alteración perjudicial para un determinado interés, en tanto que interés valorado positivamente, resulta relevante para el Derecho Penal. Al contrario, sólo serán relevantes aquéllas alteraciones que vengan dadas por un comportamiento potencialmente dañino en relación al bien jurídico protegido.

Así, actualmente, tal y como señala Mir PUIG, es posible considerar la falta de tipicidad penal mediante una interpretación restrictiva que «excluya la conducta del tipo pese a caber literalmente en ella ${ }^{10}$ ». También De la Cuesta Aguado recuerda que podemos encontrarnos con conductas

7 En términos similares ver MIR PUIG, S, Derecho Penal Parte General, Barcelona, Reppertor, 2016, p.172. También NAVARRo CARDOso, F, Infracción administrativa y delito: Límites a la intervención del Derecho penal, Madrid, Colex, 2001, p. 70.

8 Silva SÁnchez, J. M, Aproximación al Derecho Penal Contemporáneo, Barcelona, Bosch, 1992, p. 267.

9 En este sentido, considero, igual que Acale SÁnchez, que «el bien jurídico es la clave de interpretación de los sistemas penales»: Acale Sánchez, M., Los nuevos delitos sobre la ordenación del territorio y el urbanismo, $1^{\mathrm{a}}$ edición, Barcelona, Bosch, 2011, p. 116.

10 Mir PuIG, S, Derecho Penal... Ob. cit., p.170, afirmando dicho autor que: «( ) la falta de tipicidad penal puede desprenderse de la mera redacción literal de los tipos — cuando la conducta no encaja en la letra de ningún tipo penal-, pero también de una interpretación restrictiva que excluya la conducta del tipo pese a caber literalmente en ella. Ello sucede, según la doctrina actual, cuando se trata de hechos que, aun cabiendo en la literalidad típica, no implican una afectación suficiente del bien jurídico, por no ser imputable su lesión a una conducta suficientemente peligrosa (falta de imputación objetiva), por consistir el bien jurídico típico en la facultad de disponer de algo por parte de su titular y existir conformidad de éste, o por ser los hechos adecuados socialmente (adecuación social) o insignificantes (principio de insignificancia). Se habla en estos casos de causas de exclusión de la tipicidad — que deben contraponerse a las causas de justificación, las cuales presuponen la existencia de tipicidad». 
que, pese a ser formalmente típicas, si no cuentan con la suficiente lesividad material, no deben sancionarse penalmente ${ }^{11}$.

En definitiva, es posible que unos determinados hechos encajen en la redacción literal del tipo penal, pero, que, aun así, no lesionen el bien jurídico protegido por la norma y, por ello, no puedan subsumirse judicialmente en el tipo penal.

Los ejemplos jurisprudenciales de exclusión de la tipicidad más comunes los encontramos en los «actos adecuados socialmente» y los «actos insignificantes o de bagatela». Un análisis en profundidad de este tema merecería un artículo independiente, pero, con vocación meramente indicativa, puedo señalar que las llamadas acciones adecuadas socialmente o actos neutrales actúan como bases interpretativas de los delitos de modo que solamente encajará en ellos aquella conducta socialmente inadecuada. Al final, lo que conlleva la teoría de la adecuación social es que una conducta indiciariamente típica se decida atípica por su buena consideración social, al entenderse adecuada o necesaria socialmente.

Asimismo, la teoría de los actos insignificantes defiende que no deben considerarse relevantes penalmente aquellas acciones menores o de bagatela, que, aun encajando formalmente en el tipo penal, su capacidad lesiva o grado de injusto sea mínimo ${ }^{12}$.

En definitiva, entiendo que el principio del bien jurídico dota al sistema de un instrumento dogmático de irrenunciable valor hermenéutico, instrumento mediante el cual puede encontrase más fácilmente el sentido, o fin de protección de la norma (mens legis), y, con ello, favorecer la atipicidad de toda conducta que, aun colmando mecánica o literalmente el tipo, no ponga en riesgo el bien jurídico protegido por el precepto penal ${ }^{13}$.

(b) ¿Función delimitadora o función crítica?

Desde hace varios años la cuestión de si es posible limitar al poder punitivo del Estado con el instrumento del bien jurídico está en viva discusión ${ }^{14}$. La idea pasa por afirmar que en un Estado social y democrático

11 de la Cuesta Aguado, Tipicidad e Imputación Objetiva, Editorial Tirant Lo Blanch, Valencia, 1996, p. 64.

12 Por ejemplo, ver Luzón Peña, D, M, y Mir Puig, S, (coordinadores), Causas de Justificación y de Atipicidad en Derecho Penal, Editorial Aranzadi, Pamplona, 1995, p. 25 y ss.

13 Con ello podría afirmarse, como señala SHÜNEMANN, que la cuestión interpretativa más importante pasa por el esclarecimiento de cuál sea el bien jurídico típico: SHÜNEMANN BERND, El principio de protección de bienes jurídicos como puno de fuga de los límites constitucionales de los tipos penales y de su interpretación, en "La teoría del bien jurídico ¿Fundamento de legitimación del Derecho penal o juego de abalorios dogmático?», Barcelona, Marcial Pons, 2007, p. 198.

14 Roxin Claus, El concepto de bien jurídico como instrumento de crítica legislativa sometido a examen, Revista Electrónica de Ciencia Penal y Criminología, ISSN 1695-0194, 
de derecho los poderes públicos están sometidos a los principios constitucionales que rigen el ordenamiento jurídico y, por tanto, obviamente, el poder legislativo no puede, ni siquiera justificándose en una supuesta legitimidad democrática, castigar una determinada conducta simplemente porque le moleste o le disguste ${ }^{15}$.

Al contrario, si el poder legislativo quiere prohibir alguna conducta, amenazando con pena al que la cometa, deberá someterse a los límites constitucionales que restringen su campo de actuación ${ }^{16}$. Ahora bien, ¿ंes el principio del bien jurídico uno de esos límites? O, dicho de otro modo: ¿los tipos penales, configuradores de delitos que no protejan bienes jurídicos, son preceptos inconstitucionales?

Ciertamente esta cuestión ha suscitado un cierto debate doctrinal y jurisprudencial. Por ejemplo, en la Sentencia del Tribunal Supremo, de fecha 27 de mayo de 1994, podemos leer lo siguiente: «Es indudable que la doctrina y la jurisprudencia no han dado aún una respuesta definitiva a la cuestión de si las leyes que no protegen bienes jurídicos son o no constitucionalmente ilegítimas».

No obstante, nuestra Carta Magna no impone la exclusiva protección de bienes jurídicos como fundamento de la política criminal del Estado, y, por ello, entiendo que la legislación penal positiva, dentro de sus facultades competenciales, podrá superar un hipotético juicio de constitucionalidad, aun no justificando la expresa y concreta tutela de un determinado bien jurídico, siempre que, no obstante, se supere el exa-

2013. También ANDREw von HiRSch apunta que, si bien el principio del bien jurídico es la base de un sistema jurídico penal racional, últimamente parte de la doctrina acoge la función crítica del principio con escepticismo: ANDREW VON HIRSCH; El concepto de bien jurídico protegido y el principio del daño, en «La teoría del bien jurídico ¿Fundamentos de legitimación del Derecho penal o juego de abalorios dogmático?» Barcelona, Marcial Pons, 2007, p. 37

15 Tal y como nos recuerda Roxin, "Conductas tales como la de criticar duramente al gobierno, profesar convicciones extrañas o comportarse en privado de forma divergente a lo prescrito por las normas sociales no será del agrado de aquella autoridad que aprecie una ciudadanía obediente, conforme y fácil de dirigir. La historia, incluyendo el presente, muestra numerosos ejemplos de sistemas de justicia criminal que pretenden reprimir tales conductas»: Roxin, Claus, "¿Es la protección de bienes jurídicos una finalidad del Derecho penal?», en Roland HefEndehl (ed.) La teoría del bien jurídico, ¿Fundamentos de legitimación del derecho penal o juego de abalorios dogmático?, Madrid, Marcial Pons, 2007, p. 443.

16 Alonso Álamo afirma que el «constitucionalismo contemporáneo, no se conforma ya con el reconocimiento formal de derechos fundamentales o con la proclamación del principio de división de poderes sino que transita hacia la progresiva afirmación material de los citados derechos, y se expande posibilitando la aparición de una nueva teoría del Derecho. El Estado de Derecho formal deja paso al Estado de Derecho material, a un Estado social de Derecho en el que significativamente todo el poder del Estado se halla sujeto a los derechos fundamentales»: Alonso Álamo, M, Bien jurídico penal: más allá del constitucionalismo de los derechos, en «Estudios Penales y Criminológicos, Vol XXIX, ISSN 1137-7550:61-105», 2009, p. 63. 
men de la proscripción de la arbitrariedad y el siempre necesario juicio de proporcionalidad ${ }^{17}$.

Por ello, al hablar del principio del bien jurídico en el campo de la política criminal prefiero hablar más de una «función crítica» frente al poder legislativo ${ }^{18}$, y no de una "función delimitadora», la cual, (en base a la actual distribución de competencias del Estado) no tiene encaje en nuestro sistema de separación de poderes constitucionales ${ }^{19}$.

De hecho, en España, de antiguo, la doctrina constitucional es clara: la configuración de los bienes jurídicos y los tipos penales atañe a la política criminal y, a la luz del principio de separación de poderes del Estado, es potestad exclusiva y discrecional del legislador. Así, por ejemplo, en el Fundamento Jurídico segundo del Auto 216/1996, de 18 de julio, el Tribunal Constitucional resolvió lo siguiente: «corresponde a la potestad exclusiva del legislador configurar los bienes penalmente protegidos, los comportamientos penalmente reprensibles, el tipo y la cuantía de las sanciones penales y la proporción entre las conductas que se pretenden evitar y las penas con las que se intenta conseguirlo. De modo que en el ejercicio de su competencia de selección de los bienes jurídicos que dimanan de un determinado modelo de convivencia social y de los comportamientos atentatorios contra ellos, así como de determinación de las sanciones penales necesarias para la preservación del referido modelo, el legislador goza, dentro de los límites establecidos en la CE, de un amplio margen de libertad que deriva de su posición constitucional y, en última instancia, de su específica legitimidad democrática. No sólo cabe afirmar, pues, que, como no puede ser de otro modo en un Estado social y democrático de Derecho, corresponde en exclusiva al legislador el diseño de la política criminal, sino también que, con la excepción que imponen

17 Principio de proporcionalidad que sí impone un cierto límite al marco de actuación del legislador penal, cuyo respeto puede fiscalizarse, de forma muy cautelosa y limitada, por parte del Tribunal Constitucional.

${ }_{18}$ En este sentido ANDREw von HiRsch señala que, junto a la función dogmática intrasistémica, el bien jurídico tiene una función crítica que consiste en «la posibilidad de declarar la inexistencia de un bien jurídico merecedor de protección frente a supuestos de penalización de conductas meramente inmorales, como, por ejemplo la prostitución, lo que a su vez habría de llevar a concluir que dicha conducta no debería ser criminalizada»: ANDREW VON HIRSCH; El concepto de bien jurídico protegido y el principio del daño, en "La teoría del bien jurídico ¿Fundamentos de legitimación del Derecho penal o juego de abalorios dogmático?» Barcelona, Marcial Pons, 2007, p. 37.

19 En este sentido, por ejemplo, en el Fundamento Jurídico séptimo de la Sentencia del Tribunal Constitucional 11/1981, puede leerse que: «en un plano hay que situar las decisiones políticas y el enjuiciamiento político que tales decisiones merezcan, y en otro plano distinto la calificación de inconstitucionalidad, que tiene que hacerse con arreglo a criterios estrictamente jurídicos». 
las citadas pautas elementales que emanan del texto constitucional, dispone para ello de una plena libertad ${ }^{20}$.

Asimismo, en el año 2008 el Tribunal Constitucional Federal alemán ${ }^{21}$ (jurisprudencia constitucional de indudable importancia a la hora de marcar un patrón interpretativo en los países de su entorno jurídicocultural) ha tenido oportunidad de resolver, categóricamente, que «del principio del bien jurídico no cabe deducir límites para la facultad de criminalización del legislador ${ }^{22}$ ».

De todos modos, a mi juicio, en todos y cada uno de los tipos penales puede encontrarse algún interés o valor tutelado, el cual, en última instancia, puede identificarse como su bien jurídico protegido, y, por ello, la cuestión de la legitimidad de un determinado tipo penal no puede encontrarse en si aquél cuenta, o no, con algún bien jurídico tutelado: piénsese que no se está enfrentando la búsqueda de algún objeto factual, que podría fracasar, operamos en el campo de lo axiológico ${ }^{23}$, escenario en el cual, al final, siempre cabrá darse algún tipo de toma de posición valorativa (el papel lo aguanta todo) ${ }^{24}$.

En este contexto, no obstante, parte de la doctrina entiende que sólo tendrán la consideración de bienes jurídicos aquellos intereses valorados positivamente por el ordenamiento jurídico. Por ejemplo, GIMBERNAT ORDEIG señala que «todo bien jurídico es un interés, pero no todo interés alcanza la categoría de bien jurídico: éste último requiere, además, que, (...) sea valorado positivamente por el ordenamiento jurídico ${ }^{25}$ ».

Pues bien, en el presente artículo se mantiene una posición muy similar a la del autor precitado pero, con alguna nota diferencial. En este

20 Pueden encontrarse pronunciamientos constitucionales similares, entre otras muchas, en las siguientes sentencias: STC 55/1996, de 28 de marzo (FJ 6º); STC 161/1997, de 2 de octubre (FJ 9); STC 136/1999, de 20 de julio (FJ 23ㅜ).

21 BVerfGE 120, pp. 224 y ss. Asimismo, SHÜNEMANN, en relación a esta sentencia, señala expresamente que: «el Tribunal Constitucional alemán ( ) ha rechazado expresamente la doctrina del bien jurídico»: SHÜNEMANn BERnd: El Derecho penal en el Estado Democrático de Derecho y el irrenunciable nivel de racionalidad de su dogmática, Reus Editorial, Madrid, 2019, p. 54.

22 Roxin Claus, El concepto de bien jurídico Ob. cit., p. 2.

23 Relacionado, del FerRajoli podemos leer que: «Palabras como «lesión», «daño»y «bien jurídico»son claramente valorativas. Decir que un determinado objeto o interés es un «bien jurídico» y que su lesión es un «daño» es tanto como formular un juicio de valor sobre él; (...)»: FERrajoli, L, Derecho y razón. Teoría del garantísmo penal, 10 a edición (segunda reimpresión), Madrid, Trotta, 2016, p. 467.

24 En este sentido, LASCURAín SÁNCHEZ también señala que el concepto bien jurídico protegido se refiere a un concepto teórico y no a un elemento descriptivo: LASCURAíN SÁnchez, J,A: «Bien jurídico y objeto protegible», en Anuario de Derecho Penal y Ciencias Penales, vol. 60, 2007, p. 119.

25 Gimbernat Ordeig, E, «Presentación», en Roland HeFendehl (ed.), La teoría del bien jurídico, ¿Fundamento de legitimación del Derecho penal o juego de abalorios dogmático?, Madrid, Marcial Pons, 2007, p. 15 
contexto, más arriba ya he señalado que un bien jurídico formalmente es un interés tutelado jurídicamente, y, que el Tribunal Constitucional español ha resuelto reiteradamente que la selección de intereses elevables a bienes jurídicos es competencia exclusiva del legislador.

Así, a la luz de esta distribución competencial, al tratar la cuestión del bien jurídico, prefiero utilizar la dicotomía bienes jurídicos legítimos y bienes jurídicos ilegítimos: los primeros son aquellos intereses que el legislador ha protegido penalmente respetando los principios limitadores del Derecho penal, principios elaborados por la Doctrina a través de años de estudio y refinamiento dogmático de la ciencia penal. En cambio, los segundos, son aquellos bienes jurídicos que, aunque hayan superado el trámite parlamentario, se hayan promulgado y, se encuentren en vigor, al materializarse en normas penales contrarias a los postulados garantistas del Derecho penal ideal, democrático y social, deben ser objeto de crítica doctrinal.

Por ejemplo (avanzando ya cuestiones que serán desarrolladas a lo largo de este escrito), mediante la exégesis que tenga por objeto la determinación de un determinado bien jurídico podemos concluir que el tipo penal analizado tutela únicamente un valor o interés moral. Un caso paradigmático era el delito que castigaba la comercialización de pornografía de adultos entre adultos durante el franquismo: ese tipo penal, previsto en el artículo 431 del Código penal de 1973, sí contaba con un interés protegido que en última instancia podía identificarse por algunos como el bien jurídico tutelado (a saber: el interés de los retrógrada y moralmente afectados) pero, evidentemente, ese delito debía criticarse, es más exigirse su expulsión del ordenamiento jurídico, ya que, su interés penalmente protegido (exclusivamente moral), no revestía las características mínimas de legitimidad, y, por tanto, no podía considerase un bien jurídico digno de tutela penal ${ }^{26}$.

Por todo ello, la pregunta que debemos hacernos es la siguiente: ¿qué márgenes y características deben exigirse a los bienes jurídicos para que éstos puedan ser considerados valores o intereses dignos de tutela penal? Esta es la cuestión que intentaré abordar en las siguientes páginas.

26 En esta línea, de Gimbernat ORDEig podemos leer lo siguiente: «(...) detrás del "estado peligroso" de la homosexualidad o de la venta de productos anticonceptivos (castigada hasta 1978 en el art. 416 CP 1973) o de la comercialización de pornografía de adultos entre adultos (tipificada hasta 1988 por el art. 431 CP 1973) se encontraba -y todavía, en menor medida, se encuentra- el interés de los católicos "bienpensantes" en no verse heridos en los sentimientos que les ha inculcado su ortodoxia religiosa (...)»: GIMBERNat Ordeig, E, "Presentación», en Roland Hefendehl (ed.), La teoría del bien jurídico, ¿Fundamento de legitimación del Derecho penal o juego de abalorios dogmático?, Madrid, Marcial Pons, 2007, p.15. 


\section{EI alcance legítimo de protección jurídico-penal}

¿Puede existir una norma penal que, aun habiendo sido promulgada siguiendo los procedimientos legalmente establecidos, respetando la distribución de competencias del Estado, sea, no obstante, ilegítima?

Ciertamente, más arriba he señalado que, atendiendo al actual reparto de poderes constitucionales, en nuestro sistema jurídico, a la luz de la legitimación democrática que le otorga el ser el representante de la voluntad popular, el legislador puede configurar los tipos penales libremente, seleccionando para ello aquellos intereses y valores que deben ser objeto de tutela penal y, así, elevarlos a la categoría de bienes jurídicos protegidos.

Ahora bien, el problema ha sido que, en ocasiones, las competencias en materia legislativa penal se han utilizado de forma irresponsable o, al menos, descuidada, y, no pocas veces, el legislador penal se ha olvidado de los principios de última ratio ${ }^{27}$ o proporcionalidad. De hecho, en los últimos años se han materializado en tipos penales decisiones legislativas innecesarias, injustificadas y trufadas de oportunismo ${ }^{28}$. Recuérdese que, el actual Código Penal español fue aprobado en el año 1995 y ya cuenta con más reformas que años de vigencia, reformas que, recurrentemente, han servido para tipificar cada vez más delitos y aumentar progresivamente las penas de los tipos ya existentes.

También, recurrentemente, el poder legislativo no ha respetado las garantías materiales del principio de legalidad, y, con ello, ha posibilitado un cuerpo normativo que ha venido lesionando sistemáticamente los necesarios criterios de taxatividad o claridad expositiva ${ }^{29}$.

27 En este contexto, el principio de última ratio «se deriva de la especial gravedad de las consecuencias penales, de su carácter de último recurso dentro del sistema de control social y de la propia comprensión de la pena como un mal sólo justificado por su necesidad para mantener los presupuestos de la convivencia»: Muñoz Conde, F., García ARÁn, M, Derecho Penal Parte General... Ob. cit. p. 76.

${ }_{28}$ Modificaciones legislativas cuyo objetivo, en ocasiones, más parece ser la satisfacción temporal de una opinión pública desinformada (o incluso manipulada) por algunos medios de comunicación (que vienen utilizando la alarma criminal -a menudo exageradacomo medio de competencia televisiva) que no una adecuada política criminal racional. Un desarrollo argumentativo de esta crítica desbordaría el objeto y alcance del presente artículo; de todos modos, el lector interesado puede encontrar esta cuestión trabajada en, por ejemplo: Diez RIPOLlÉs, J,L: La racionalidad de las leyes penales, editorial Trotta, Madrid, 2003; y, en especial, García Arán, M y Botella Corral, J, (directores): Malas noticias. Medios de comunicación, política criminal y garantías penales en España, Valencia, Tirant lo Blanch, 2009.

29 Un campo abonado a lo que aquí estoy apuntando lo encontramos en aquellos ilícitos penales que tienen su reflejo en normas administrativas sancionadoras, donde los espacios de solapamiento entre infracciones de ambos ordenamientos, por culpa de carencias técnico-legislativas, son habituales. Un caso paradigmático de lo aquí señalado es, por ejemplo, el delito urbanístico: en este sentido, actualmente, exactamente la misma 
A mi juicio, la explicación de esta dinámica legislativa la podemos encontrar en el fenómeno del populismo punitivo, el cual, puede entenderse a partir de la suma de tres factores interdependientes, a saber: (i) unos medios de comunicación que han descubierto la explotación de la noticia criminal, cuanto más penosa mejor, como método de competencia audiovisual; (ii) una opinión pública sensible y permeable a cada nuevo escándalo televiso, que exige indignada soluciones; y, (iii) un poder legislativo irresponsable que, a la luz de todo lo anterior, decide satisfacer las exigencias de los ciudadanos tipificando nuevos delitos y agravando las consecuencias jurídicas de los tipos (cual solución mágica se tratara). En este tema considero que falta pedagogía jurídica y sobra mucha demagogia política ${ }^{30}$.

En este contexto, algunos autores, como DiEz RIPOLLÉs, han empezado a reivindicar la necesidad de sentar las bases de la ciencia de la legislación penal como paso previo a conseguir «sacar las leyes penales del conyunturalismo que ahora padecen y reintegrarlas al campo del debate racional ${ }^{31}$ ».

Ahora bien, no podemos (ni debemos) conformarnos simplemente con la realidad político-legislativa que nos ha tocado soportar. En este sentido, un Derecho penal positivo «ideal» es aquél que, además de gozar de plena legalidad formal, es materialmente legítimo, es decir, que respeta los límites y garantías que deben exigirse al ius puniendi de un Estado social y democrático de Derecho, que propugna como valores superiores

conducta, edificar una construcción no autorizable en suelo clasificado como no urbanizable (sin importar el volumen de la construcción y sin atender a la calificación del suelo), es una acción que tanto puede subsumirse literalmente en el artículo 319.2 del Código Penal como, perseguirse por medio de un procedimiento administrativo sancionador.

30 En este sentido, hace casi veinte años que Quintero OlIVARES publicó las siguientes palabras, las cuales siguen estando de tremenda actualidad: «(...) lo cierto es que se percibe una constante demanda de reformas, ampliaciones, nuevas tipificaciones del número de amenazas penales que contienen las leyes. Esa huida sistemática al derecho punitivo como refugium peccatorum sólo puede explicarse cómo modo demagógico de satisfacer a la llamada opinión pública, mientras que se desprecia o ignora que el grado de ineficacia consustancial al sistema penal resultará más patente y lamentable conforme se haga crecer el marco de tareas que se le asignan»: Quintero OLIVARES, G, La Justicia Penal en España, Pamplona, Aranzadi, 1998, pp. 35 y 36.

31 Por ejemplo ver Diez Ripollés, J,L. La racionalidad de las leyes penales, editorial Trotta, Madrid, 2003, en cuya obra, además de criticar la dinámica legislativa penal de los últimos años, argumenta, de forma muy inteligente y oportuna, que deberían recuperarse las tradiciones ilustradas y codificadora, las cuales, consideraban que el principal objetivo de los juristas era asegurar la racionalidad de las leyes; o, Diez Ripollés, J,L. Delitos y penas en España, editorial Catarata, Madrid, 2015, obra donde éste autor sigue reivindicando la búsqueda de una necesaria racionalidad legislativa, y, asegura, (en su página 10) que, «actualmente, el código penal se ha convertido, en manos de nuestros agentes políticos, en un formidable instrumento de propaganda, con el que se encubren políticas defectuosas de cualquier signo mediante una desmedida explotación de emociones colectivas». 
de su ordenamiento jurídico la libertad, la justicia, la igualdad y el pluralismo político.

Por ello, al objeto de depurar el nivel de legitimidad del Derecho penal contemporáneo, deberemos analizarlo a la luz del principio del bien jurídico protegido, principio del cual pueden deducirse una serie de criterios mínimos de legitimidad y justificación de la norma penal.

Esta afirmación la encontramos en FERRAJOLI, el cual señala que de la teoría del bien jurídico podemos extraer los criterios negativos de deslegitimación cuya lesión permite «afirmar que una determinada prohibición penal o la punición de un concreto comportamiento prohibido carecen de justificación, o que ésta es escasa» ${ }^{32}$.

Así, el principio del bien jurídico nos ayudará a detectar aquellos tipos penales que, no obstante haberse promulgado legalmente, deben criticarse doctrinalmente. Veamos, pues, a continuación, algunas de las características de legitimidad que pueden usarse para determinar el grado de legitimidad material del bien jurídico protegido.

\section{Los valores o intereses morales como límites de tutela penal}

Dentro de la delimitación negativa del concepto bien jurídico protegido deben incluirse todas aquellas normas penales que tengan como objeto la simple protección de posiciones morales. De hecho, ya se parta de una concepción monista-individualista del bien jurídico, como de una visión sociológica-funcionalista del principio, se observará que, a pesar de las diferencias conceptuales, ambas posturas dogmáticas comparten transversalmente, en cierta medida, la misma postura crítica y de oposición frente a los delitos morales.

En este contexto, por ejemplo, FERRAJOLI, en su monumental obra Derecho y razón, cuando trata los principios de necesidad y lesividad de los

32 Ferrajoli, L, Derecho y razón... Ob cit, p. 471, donde, concretamente, se apunta lo siguiente: «una teoría del bien jurídico no puede casi nunca decirnos positivamente $-\mathrm{y}$ además no serviría de nada que nos lo dijera- que una determinada proposición penal es justa en cuanto protege un determinado bien jurídico. Puede ofrecernos únicamente una serie de criterios negativos de deslegitimación - que no son sólo la irrelevancia o evanescencia del bien tutelado sino también la desproporción con las penas previstas, la posibilidad de una mejor protección con medios no penales, la inidoneidad de las penas para lograr una tutela eficaz, o, incluso, la ausencia de lesión efectiva a causa del comportamiento prohibido- para afirmar que una determinada prohibición penal o la punición de un concreto comportamiento prohibido carecen de justificación, o que ésta es muy escasa. Pero, por otra parte, esto es todo lo que se pide a la categoría del «bien jurídico», cuya función de límite o garantía consiste precisamente en el hecho de que la lesión de un bien debe ser condición necesaria, aunque nunca suficiente, para justificar su prohibición y punición como delito». 
bienes jurídicos, señala que el principio de utilidad penal, en confluencia con el principio axiológico de la separación entre "derecho y moral», determina que el Derecho penal solamente está legitimado para castigar aquellas acciones reprobables por sus efectos lesivos frente a terceros, tachando de ilegítimas todas aquellas leyes penales que impongan prohibiciones respecto de comportamientos meramente inmorales ${ }^{33}$.

También, para que el principio del bien jurídico pudiera gozar de una efectiva capacidad crítica legislativa, estableciéndose un marco de intereses protegibles fuera de los cuales las normas penales podrían tacharse de ilegítimas, se elaboraron los conceptos sociológico-funcionalistas del bien jurídico, «teoría que permitió vincular la legitimidad del Derecho penal, en el marco del bien jurídico protegido, con la teoría de la dañosidad social ${ }^{34}$ » y que, por extensión, negó la posibilidad de sancionar penalmente conductas justificadas solamente en un hipotético valor moral lesionado.

A mayor abundamiento, en los países anglosajones (en los cuales no se utiliza el principio del bien jurídico protegido) la base de legitimación de las normas penales se encuentra en el principio del daño o Harm Principle, construido esencialmente a la luz de los postulados desarrollados por John Stuart MiLl en su obra On Liberty ${ }^{35}$. Según este filósofo británico, el Estado no puede utilizar las normas coercitivas para imponer al individuo un tipo de moralidad determinada y, en esta línea de pensamiento, solamente estarían legitimadas las normas punitivas

33 Ferrajoli, L, Derecho y razón, Ob cit., pp. 464 y 465.

34 Al respecto Silva SÁNCHEZ señaló que, en el pasado reciente, el bien jurídico albergaba una concepción más vinculada a un posible "valor (espiritual-cultural) difundida por el neokantismo, que prácticamente lo incapacita para cumplir fin limitador alguno»: Silva SÁnchez, J. M, Aproximación al Derecho Penal Contemporáneo, Barcelona, Bosch, 1992, p. 268; obra en la cual el mismo autor sigue apuntando que: «si el bien jurídico se entiende únicamente como una "realidad valorada positivamente», parece obvio que bajo esa initulación puede incluirse cualquier estado, convicción o principio, en función del sector social dominante en una sociedad determinada. La ineficacia garantística de la concepción espiritualista del bien jurídico como materialización de un valor se advierte tan pronto como se piensa en que el Derecho penal nacionalsocialista no tuvo dificultades importantes para acabar aceptando un concepto de bien jurídico de tal factura, rechazando inicialmente por sus connotaciones liberales».

35 John Stuart Mill, On Liberty, 1859. En el Capítulo cuarto de la obra, titulado, of the Limits to the Authority of Society over the Individual, el autor desarrolla este tema, no obstante, es en el capítulo Introductorio donde podemos leer con toda claridad que, según este pensador: "the only purpose for which power can be rightfully exercised over any member of a civilised community, against his will, is to prevent harm to others. His own good, either physical or moral, is not a sufficient warrant. He cannot right-fully be compelled to do or forbear because it will be better for him to do so, because it will make him happier, because, in the opinions of others, to do so would be wise, or even right. These are good reasons for re-monstrating with him, or reasoning with him, or persuading him, or entreating him, but not for compelling him, or visiting him with any evil in case he do otherwise. To justify that, the conduct from which it is desired to deter him must be calculated to produce evil to someone else». 
cuando sirvieran para impedir que los individuos causaran daños a sus semejantes ${ }^{36}$.

En definitiva, como puede observarse, en las distintas concepciones del bien jurídico referidas puede identificarse un postulado común, a saber: una oposición categórica a toda norma penal que no pueda justificar un valor o interés superior al de la mera tutela moral ${ }^{37}$.

Pues bien, actualmente (afortunadamente) en España hay un acuerdo prácticamente unánime, doctrinal ${ }^{38}$ y jurisprudencial ${ }^{39}$, según el cual deben reputarse ilegítimas todas aquellas normas penales motivadas por simples intereses ideológicos o morales.

La moral oficial o pública puede reivindicarse y celebrarse en foros privados de participación optativa. Cada cual es libre de profesar la ideología y creencias que estime convenientes, pero, el poder punitivo del Estado debe limitar su intervención para asegurar la defensa de los derechos e intereses (individuales o colectivos) que sean necesarios para

36 En este sentido ANDREw VON HIRSCH apunta que: «Así concebido, «el «principio del daño» ha sido utilizado en la discusión angloamericana como argumento frente a la prohibición penal del consumo de alcohol, de la prostitución o de la homosexualidad»: ANDREW VON HIRSCH; El concepto de bien jurídico protegido y el principio del daño, en «La teoría del bien jurídico ¿Fundamentos de legitimación del Derecho penal o juego de abalorios dogmático?» Barcelona, Marcial Pons, 2007, p. 39.

37 De todos modos, parte de la doctrina ha criticado las concepciones sociológicas, tachándolas de disfuncionales a la hora de edificar un bien jurídico potencialmente limitador del legislador penal. Por ejemplo, Alonso Álamo ha señalado (creo que desde un plano esencialmente iusnaturalista) que «ni el daño social, ni el principio del daño a otro están en condiciones de proporcionar criterios limitadores de la criminalización», apostando esta autora por ligar el concepto del bien jurídico protegido con el sistema de valores que ofrece el catálogo de derechos humanos pre-positivos: Alonso Álamo, M: Fundamentación pre-positiva de los bienes jurídicos-penales y Derecho penal mínimo de los Derechos Humanos, en «Iustel, Revista General de Derecho Penal - 15», 2011, p. 14.

38 De entre muchos otros, de Berdugo Gómez DE LA ToRRE podemos leer que, hasta hace poco tiempo, algunos delitos todavía encontraban su justificación en razones exclusivamente éticas, pero, al respecto, «un sector doctrinal proyectó todas las consecuencias del debate en torno al bien jurídico que se produce en la década de los sesenta y que llevaron a la exclusión por el legislador de su relevancia penal, pues acertadamente se entendía que sólo una razón ética estaba detrás de su presencia en los códigos penales y esta justificación era incompatible con las exigencias del modelo de Estado constitucionalmente consagradon: Berdugo Gómez de la TORRe, I: Viejo y nuevo Derecho penal. Principios y desafíos del Derecho penal de hoy, Iustel, Madrid, 2012, pp. 234 y 235.

39 Por ejemplo, en la STS de fecha 27 de mayo de 1994 podemos leer lo siguiente: «Cierto es, sin embargo, que en el contexto de esta problemática en la doctrina se reconoce, al menos, que "la protección de normas morales, religiosas o ideológicas, cuya infracción carece de toda consecuencia social, es una cuestión que no pertenece a los propósitos de un Estado de Derecho democrático" y que el derecho general a la libertad de acción sólo debería ser limitado en los casos de infracción de «normas éticas elementales, cuya observancia está impuesta no por sí mismas, sino para evitar efectos socialmente dañosos». 
que los ciudadanos podamos desarrollar libremente nuestro plan vital en sociedad.

En definitiva, en el marco de los criterios de función y utilidad social, criterios que deben exigirse al ordenamiento jurídico en su conjunto, siempre, desde nuestra tradición liberal e ilustrada, procurándose el justo equilibrio entre la protección de intereses sociales y los derechos fundamentales individuales, las posiciones morales o ideológicas (incluso las socialmente mayoritarias) no pueden reputarse valores dignos de tutela penal.

\section{2. ¿Bienes individuales o bienes colectivos?}

Algunos intereses no plantean especiales objeciones a la hora de poder ser considerados bienes jurídicos penalmente legítimos. Por ejemplo: la vida humana, la salud, la libertad o el patrimonio son intereses fundamentales sin los cuales ningún individuo podría lograr plenamente el desarrollo de su plan vital.

No vivimos en un mundo ideal, la realidad de nuestro entorno está preñada de actos violentos y escenarios peligrosos. Los ataques por parte de otros miembros de la comunidad son una posibilidad real y, por tanto, estos intereses fundamentales, los más importantes de cuantos contamos, deben elevarse a la categoría de bienes jurídicos protegidos ${ }^{40}$.

De hecho, de antiguo se protegen en nuestros ordenamientos jurídico-penales este tipo de bienes jurídicos, configurándose éstos como intereses tradicionales o bienes jurídicos individuales. La batalla ideológica, por ello, se encuentra en otro campo de intervención legislativa, a saber: el de los nuevos intereses sociales generales y difundidos (no difusos ${ }^{41}$ ) nacidos a partir del fenómeno de la expansión del Derecho penal, intereses que se han conceptualizado como bienes jurídicos colectivos.

40 Tal y como señalan Muñoz CONDE, F., GARCía ARÁN, M, «sería mejor o, por lo menos, más agradable que alguna vez la violencia dejara de gobernar las relaciones humanas. Pero en ningún caso podemos deformar ideológicamente los hechos y confundirlos con nuestros más o menos buenos o bienintencionados deseos»: MuÑoz CondE, F., García ARán, M, Derecho Penal Parte General, Valencia, Tirant lo Blanch, 2015, p. 31. También Quintero OlIVARES nos recuerda que «El ideal abolicionista de una sociedad que no necesitara usar la represión es, por desgracia, una utopía»: Quintero Olivares, G, (Dir.), Derecho Penal Constitucional, Valencia, Tirant lo Blanch, 2015, p. 22.

41 Una cuestión terminológica: en la literatura jurídica española se encontrará la referencia a los «intereses difusos» en vez de a los «intereses difundidos», no obstante, posiblemente, ello es producto de una discutible traducción del concepto acuñado en la ciencia jurídica italiana, de los «interessi diffusi e collettivi», cuya traducción literal sería la de los «intereses difundidos y colectivos». La diferencia no es meramente formal, así: en lengua española un interés difuso es un interés poco concretado o impreciso; en cambio, un interés difundido es sinónimo a un interés extendido o generalizado. 
Efectivamente, a partir de la nueva realidad del Derecho penal, encontramos otros intereses sociales protegidos penalmente, que se han elevado a la categoría de bienes jurídicos colectivos asumiendo que su protección interesa al grupo social en su conjunto. En general la doctrina acepta la incorporación de estos intereses macrosociales al catálogo de bienes jurídicos protegibles. La excepción más relevante la encontramos en la Escuela de Frankfurt, cuya línea argumental, encabezada por HasSEMER, defiende que solamente deberían poderse categorizar como bienes jurídicos protegidos los bienes jurídicos individuales. No comparto esta tesis académica ${ }^{42}$.

En este contexto, el Derecho penal debe actualizarse según el modelo de sociedad en la cual tiene que ser aplicado. El Código Penal sirve para tutelar los intereses más importantes para el individuo o la sociedad, sin que quepa oponer posiciones limitadoras de corte clasista que pasarían por asumir que los intereses de la clase propietaria seguirían tutelados por el Derecho penal pero, que los intereses de la comunidad en su conjunto, aun demostrándose fundamentales para el libre desarrollo del individuo en sociedad, fueran despreciados y relegados sin excepción a instancias inferiores ${ }^{43}$.

Entre estos intereses colectivos, respecto de los cuales el Derecho Penal debe intervenir, podemos encontrar ejemplos como la ordenación del territorio, el medio ambiente, la salud pública, la seguridad colectiva, la organización política, etc ${ }^{44}$.

42 Tampoco, por ejemplo, AcAlE SÁNCHEZ, autora que oportunamente critica que si el Derecho penal no puede ocuparse de los intereses colectivos ello implicaría inescindiblemente no intervenir en comportamientos que afectarían, por ejemplo, «al colectivo de trabajadores obligados a trabajar en condiciones peligrosas para su vida o su salud, porqué así los empresarios ahorran costes; al disfrute por parte de la colectividad de los espacios verdes, a manos de aquellos constructores que se lucran con la función social de la propiedad, etc; la apropiación del patrimonio público por parte de los funcionarios encargados de su distribución según criterios de razonabilidad cuando lo hacen según sus particulares necesidades» Acale Sánchez, M, Los nuevos delitos... Ob. cit.

${ }^{43}$ En términos más categóricos expresa su crítica a la Escuela de Frankfurt PorTILLO CONTRERAS, autor que señala lo siguiente: «en realidad, esta propuesta es claramente discriminatoria pues no hace sino confirmar lo que todos sabemos: que la prisión queda reducida a la lesión de los intereses de la propiedad individual, mientras que las minorías propietarias se ven relegadas del derecho a ser privados de libertad satisfaciendo sanciones económicas»: Portillo Contreras, G, «La protección del derecho al medio ambiente y los derechos económicos-sociales en un periodo de crisis del Derecho y del Estado de Derecho» en Quintero Olivares, G, y, Morales Prats, F (Coords.), Estudios de Derecho ambiental, Valencia, Tirant Lo Blanch, 2008, p. 283.

${ }^{44}$ En este sentido, y vinculado con las nuevas expectativas de tutela colectiva, QuiNTERO OlIVARES explica que: «Con grandes dificultades el español medio fue adquiriendo la conciencia de que, por obra de la Constitución, dispone de un patrimonio político subjetivo, que en muchos aspectos tendrá que proteger el Derecho penal. Pero hoy, y con mucha rapidez, asume su coparticipación en la titularidad social y colectiva de esenciales bienes y valores, como puedan ser la salud, la educación o el medio ambiente. Los derechos sociales han generado, como es lógico, expectativas de conducta de los poderes públicos de 


\section{El bien jurídico "penalmente» protegido y la cuestión de la intervención mínima penal}

La teoría del bien jurídico protegido importa tanto al derecho penal como al derecho administrativo sancionador ${ }^{45}$, es decir, afecta por igual a todo el ordenamiento jurídico punitivo del Estado, acogiéndose por tanto en este artículo la teoría de la diferenciación cuantitativa (no cualitativa ${ }^{46}$ ) de ambos ordenamientos sancionadores ${ }^{47}$.

De hecho, todas las normas prohibitivas comparten fundamento de punición. Cualquier norma que pretenda castigar una determinada conducta humana será ilegítima si detrás de la misma no hay un interés (o bien jurídico protegido) reconocible, cuya tutela sirva, al menos en última instancia, a la protección de los derechos individuales. Con ello, además, «hemos llegado en España a una fase en la que ya no se discute «si» los principios del Derecho Penal se aplican al Derecho Administrativo Sancionador, puesto que así se acepta con práctica unanimidad ${ }^{48}$ ».

Por tanto, está común y pacíficamente aceptado que el Derecho penal no es el único medio de protección posible. Es más, en la STC 18/1981, de 8 de junio en relación al ámbito de protección del bien jurídico, también en sede administrativa, puede leerse lo siguiente: «Para llevar a cabo dicha interpretación, ha de recordarse que los principios inspiradores

los que se esperan, legítimamente, actos concretos encaminados a la preservación de esos bienes o al desarrollo de las llamadas promesas constitucionales. El Derecho penal no puede ser ajeno a ello y, consecuentemente, ha tenido que incorporar nuevas áreas de intervención en coherencia con esa transformación del orden de valores colectivo propiciado por la Constitución, y así se han de entender, con sus virtudes, limitaciones y defectos, los delitos de riesgo colectivo, los ambientales, económicos, los relativos a la corrupción, a la discriminación, a los deberes de los funcionarios públicos, que han experimentado una progresiva adaptación al marco constitucional, de acuerdo con la evolución social reciente»: Quintero Olivares, G, (Dir.), Derecho Penal Constitucional, Valencia, Tirant lo Blanch, 2015, p. 27.

45 En este contexto, parte de la doctrina defiende que el concepto del bien jurídico, al ser utilizado por otras disciplinas, debe ser considerado plenamente como un concepto de la Teoría General del Derecho y no solamente como una cuestión de dogmática penal: Amelung, K., El concepto «bien jurídico» en la teoría de la protección penal de bienes jurídicos, en «La teoría del bien jurídico, ¿Fundamentos de legitimación penal o juego de abalorios dogmático? », Marcial Pons, Madrid, 2007, p. 227.

${ }_{46} \mathrm{O}$ también, si se prefiere, usando la terminología de la «identidad ontológica» entre los delitos y las infracciones administrativas. En este contexto, ver, por ejemplo, la STS de 19 de noviembre de 2001, o la STSJ de Aragón de 12 de abril de 1993.

47 En este contexto, por ejemplo, NiETo GARcía asegura, en relación a las garantías exigibles en los ordenamientos punitivos del estado (administrativo sancionador y penal) que: «Los principios inspiradores del Derecho Penal son progresistas en cuanto que suponen una garantía de los derechos de los individuos. De aquí que sea más conforme con el espíritu democrático de la Constitución -y con el Estado de Derecho- la igualación «por arriba» de ambos ordenamientos»: NIETo GARCía, A., Derecho Administrativo Sancionador, Madrid, Tecnos, 2012, p. 134.

48 Nieto García, A., Derecho Administrativo... Ob. cit., p. 132. 
del orden penal son de aplicación, con ciertos matices, al derecho administrativo sancionador, dado que ambos son manifestaciones del ordenamiento punitivo del Estado, tal y como refleja la propia Constitución (artículo 25: principio de legalidad) y una muy reiterada jurisprudencia de nuestro Tribunal Supremo (Sentencia de la Sala Cuarta de 29 Septiembre, 4 y 10 Noviembre 1980, entre las más recientes), hasta el punto de que un mismo bien jurídico puede ser protegido por técnicas administrativas o penales, si bien en el primer caso con el límite que establece el propio artículo 25.3, al señalar que la Administración Civil no podrá imponer penas que directa o subsidiariamente impliquen privación de libertad».

En este contexto, del listado de intereses que pueden clasificarse como bienes jurídicos protegibles por el Estado, y a la luz del principio de última ratio, el Derecho penal solamente debe proteger los más importantes y relevantes para el individuo y la sociedad y únicamente frete a los ataques más graves e intolerables que aquéllos sufran (carácter fragmentario), siempre que, los demás medios de tutela o intervención del Estado no sean suficientes (carácter subsidiario) ${ }^{49}$.

Los bienes jurídicos que no superen la doble premisa pueden igualmente protegerse, pero su tutela, a la luz del principio de intervención mínima, debe confiarse a otros medios de tutela y sanción menos gravosos, como, por ejemplo: una adecuada política social preventiva, o, quizá, la utilización de normas de carácter administrativo sancionador.

Atendiendo a todo ello, cuando nos estemos refiriendo a bienes jurídicos protegidos por el Derecho penal más precisa sería una definición como bienes jurídico-penales en contraposición con los bienes jurídicoadministrativos, y, por ello, sería deseable que se generalizara esta terminología ${ }^{50}$.

Ahora bien, no puedo dejar de insistir que, a la luz del principio de intervención mínima, el Derecho penal debería utilizarse solamente para tutelar los valores e intereses más importantes del sistema de convivencia social, contra el catálogo de ataques potencialmente más lesivos ${ }^{51}$. Pues

49 Como se observa, en este artículo acojo la estructura del principio de intervención mínima ideada por el maestro MuÑoz CondE en 1975, desarrollada por primera vez en su obra: Introducción al Derecho penal, Barcelona, Editorial Bosch, primera edición, 1975, pp. 107 y ss. Hoy también en: Muñoz Conde, F., García ArÁn, M: Derecho Penal Parte General, Valencia, Tirant lo Blanch, 2015, p. 77 y ss.

50 También, en estos términos, se expresa MiR PuIG, S., Derecho Penal... Ob. cit., p.172

51 Evidentemente, se reconoce en este trabajo el grado de dificultad que pesa sobre el legislador a la hora de llevar a cabo la selección de bienes jurídicos que deben protegerse penalmente. Pero, por ejemplo, afirmo que cuando se susciten importantes dudas sobre la justificación del recurso penal como medio de tutea y sanción, ello es un indicio del mejor recurso administrativo sancionador. A mayor abundamiento, y como método de selección orientativo garantista, FERRAJOLI señala que: «ningún bien justifica una protección penal 
bien, es muy discutible que nuestro Código penal actual respete el principio apuntado.

Por ejemplo, el artículo 384 del Código penal (in fine) castiga al que conduzca (también perfectamente bien) un vehículo a motor sin haber obtenido nunca el permiso de circulación. Identificando el bien jurídico con la seguridad vial, quizá en este supuesto de hecho sería más razonable, siempre que el conductor no haya conducido de forma imprudente, ventilar esta cuestión en sede administrativa sancionadora, más aun conociendo que la norma administrativa sobre circulación de vehículos a motor prevé la misma infracción típica ${ }^{52}$.

También, por ejemplo, el artículo 217 del Código penal sigue castigando con penas de prisión al que contrajere segundo o ulterior matrimonio, a sabiendas de que subsiste legalmente el anterior. Parece poco razonable defender la legitimidad del tipo penal que protege el modelo familiar tradicional y castiga la bigamia (o poligamia) libremente consentida, salvo que aquélla fuera el medio necesario para perjudicar a alguien (previsto expresamente en el artículo 218 del Código penal) o, el instrumento para cometer algún tipo de estafa o fraude al Estado. Si no concurrieran los elementos justificadores expuestos bastaría con declarar la nulidad del segundo matrimonio más sancionar con una multa administrativa, en su caso, al autor.

Al respecto de todo lo manifestado hasta aquí, el Auto 233/2004, de 7 de junio, del Tribunal Constitucional, señala expresamente que, desde la óptica constitucional, cabrá fallarse la innecesaridad de la norma penal "cuando a la luz del razonamiento lógico, de datos empíricos no controvertidos y del conjunto de sanciones que el mismo legislador ha estimado necesarias para alcanzar fines de protección análogos, resulta evidente la manifiesta suficiencia de un medio alternativo menos restrictivo de derechos para la consecución igualmente eficaz de las finalidades deseadas por el legislador».

También Roxin defiende que el «Derecho penal tiene como finalidad procurar a los ciudadanos una existencia pacífica, libre y socialmente segura, en la medida en que tales objetivos no puedan conseguirse mediante otras medidas socio-políticas menos intrusivas en la esfera de libertad de los ciudadanos»y, además, señala que «lo ideal es que el poder de intervención estatal y la libertad de los ciudadanos se lleven a un equilibrio

-en lugar de una civil o administrativa- si su valor no es mayor que el de los bienes de que priva la pena»: FerRAJOLI, L, Derecho y razón... Ob cit, p. 472.

52 En concreto, en el artículo 77. k) del Real Decreto Legislativo 6/2015, de 30 de octubre, por el que se aprueba el texto refundido de la Ley sobre Tráfico, Circulación de Vehículos a Motor y Seguridad Vial, se tipifica como infracción muy grave «conducir un vehículo careciendo del permiso o licencia de conducción correspondiente». 
que le garantice al individuo tanta protección como sea necesaria, pero también tanta libertad individual como sea posible ${ }^{53}$ ".

En definitiva, una vez detectado el bien jurídico protegido por el tipo penal eventualmente estudiado, si aquél interés o valor se aprecia de poca relevancia o de menor importancia, o, también, cuando se asuma que los mismos resultados tutelares pueden alcanzarse en otras instancias menos gravosas que el recurso penal, debe criticarse su elección punitiva y trabajarse para fomentar su destipificación penal.

\section{4. ¿Son los sentimientos humanos un objeto legítimo de protección penal?}

En la actualidad algunos autores vuelven a discutir sobre la idoneidad de los sentimientos humanos como intereses tutelables por el Derecho penal y, con ello, su eventual reconocimiento como bienes jurídicos penalmente protegidos.

Esta discusión jurídica ha recobrado protagonismo en algunos nuevos tipos penales controvertidos, en los cuales, los defensores del principio de protección de bienes jurídicos (aun admitiendo una correcta y conveniente tipificación del precepto) encuentran dificultades para poder encontrar un fundamento de tutela.

Un ejemplo paradigmático de lo anterior lo encontramos en el actual artículo 337 del Código penal, el cual, castiga con penas de prisión a los que maltraten a determinados animales ${ }^{54}$. En este sentido, en relación a este tipo delictivo, puede observarse que, entre la doctrina favorable a su tipificación, se manejan esencialmente los siguientes posibles bienes jurídicos justificantes: (i) el vinculado al derecho de propiedad del titular del animal; (ii) el que, axiológicamente, reconoce algún tipo de derecho natural del animal digno de protección penal; (iii) el que entiende que cabe defender, en un marco iuspositivista, el derecho del bienestar animal en

53 Roxin, Claus, «¿Es la protección de bienes jurídicos...» Ob. cit., p. 446 y 447, donde este autor sigue señalando que «Según la concepción ideal del contrato social, los ciudadanos, detentadores del poder estatal, ceden al legislador sólo aquellas facultades penales que son necesarias para alcanzar una convivencia libre y pacífica, y sólo en la medida en que este fin no se pueda conseguir por medios más suaves».

${ }^{54}$ Artículo 337.1 del Código penal: «1. Será castigado con la pena de tres meses y un día a un año de prisión e inhabilitación especial de un año y un día a tres años para el ejercicio de profesión, oficio o comercio que tenga relación con los animales y para la tenencia de animales, el que por cualquier medio o procedimiento maltrate injustificadamente, causándole lesiones que menoscaben gravemente su salud o sometiéndole a explotación sexual, a: (a) un animal doméstico o amansado, (b) un animal de los que habitualmente están domesticados, (c) un animal que temporal o permanentemente vive bajo control humano, o (d) cualquier animal que no viva en estado salvaje». 
el campo del Derecho penal; y, (iv) el relacionado con la posible lesión de sentimientos humanos vinculados directamente al maltrato animal.

En este contexto, entiendo que la primera posibilidad entra en crisis cuando se enfrenta a la posible lesión del animal que seguiría disponiendo el titular o propietario del mismo. También, en relación a la segunda y tercera postura, ciertamente, convengo que la sociedad puede (y debe) proteger algunos intereses de algunos animales, pero, no puedo compartir ni aquellas posiciones que aseguran que los animales disponen de algún tipo de «derecho natural» ${ }^{55} \mathrm{ni}$, tampoco, estimar conveniente que, a través del pacto político legislativo, utilicemos el Derecho penal para defender el derecho, directamente del animal, a su propio bienestar ${ }^{56}$.

Asimismo, y en relación a la cuarta posible argumentación, es evidente que, en la actualidad, existe un sentimiento de dolor o malestar cada vez más generalizado en la sociedad cuando se contemplan actos injustificados de maltrato animal. No obstante, elevar a la categoría de bien jurídico este sentimiento, simplemente por ser un sentimiento dominante o mayoritario en una determinada sociedad, se enfrenta a todo tipo de objeciones de coherencia jurídica, al menos, si aceptamos que el sentimiento, por ejemplo, del rechazo a la homosexualidad, aun en un eventual escenario de aceptación social mayoritaria, no justificaría, a la luz del principio del bien jurídico protegido, la punición de esas conductas humanas libremente consentidas.

En relación a este punto, una posible solución de legitimación es la ofrecida por el profesor GIMBERNAT ORDEIG, el cual, defiende la legítima punición de las conductas de maltrato animal en la posible conceptualización de un determinado sentimiento humano colectivo como bien jurídico protegido, siempre que aquél sea un "sentimiento legítimo», esto es: que para la tutela de ese sentimiento no se lesionen derechos

55 En este sentido, de la filósofa AdELA CoRTina podemos leer que: «Hablar de derechos de los animales anteriores al pacto político, por el contrario, carece de base. Es un discurso que se emplea con fines políticos, con el fin de proteger del daño a seres vulnerables. Pero carece de fundamento racional y por eso más vale reconocer que los animales son valiosos, que es un deber no dañar a los seres con capacidad de sufrir y proponer normativas legales, pero no manejar el discurso de unos presuntos derechos naturales de los animales (...)»: CORTINA ORTS, A: Las fronteras de la persona, El valor de los animales, la dignidad de los humanos, editorial Taurus, Madrid, 2009, p. 226.

56 A mi juicio, la visión antropocéntrica del Derecho es la tesis de filosofía jurídicopolítica acertada. El Derecho es un instrumento creado "por» y "para» el ser humano. En este sentido, por ejemplo, Claus Roxin afirma que: «la persona es el amo de la creación, porque es el único ser viviente capaz de garantizar su preservación (...)». Y, sigue apuntando que: «(...) la ampliación del concepto del bien jurídico para abarcar el sufrimiento de los animales se explica a partir de nuestra solidaridad con las criaturas»: CLAus Roxin: La teoría del Delito en la discusión actual, Tomo II, Grijley, Lima, 2015, pp. 64 y 65. 
fundamentales reconocidos constitucionalmente, como sí ocurriría, por ejemplo, en el caso de castigarse penalmente la homosexualidad ${ }^{57}$.

Ahora bien, en páginas anteriores he defendido que las posiciones morales no pueden imponerse por medio del ordenamiento jurídico del Estado, y, por ello, consecuentemente, considero que el «sentimiento de rechazo» que tienen algunas personas cuando contemplan determinados comportamientos humanos contrarios a "su moral», no puede ser objeto de tutela.

En consecuencia, antes de que podamos valorar si los sentimientos humanos pueden considerarse bienes jurídicos «penales» legítimos, deberemos considerar, previamente, si los sentimientos pueden ser, siquiera, bienes jurídicos "genéricos» legítimos, y, con ello, intereses susceptibles de obtener algún tipo de tutela legal.

Pues bien, mi posición es favorable a esta posibilidad, siempre que, no obstante, seamos capaces de diferenciar previamente las estructuras de los «sentimientos morales» de los «sentimientos emocionales». Me explico: así como la moral es la «doctrina del obrar humano que pretende regular el comportamiento individual y colectivo en relación con el bien y el mal y los deberes que implican» ${ }^{58}$, los sentimientos «representan pautas de actividad cerebral que indican emociones, intenciones y pensamientos ${ }^{59}$ ». En este sentido, para la existencia de sentimientos morales se requiere previamente una posición moral determinada, la cual, tributa inescindiblemente de una determinada educación (familiar, social, institucional,...), ésta es elaborada, trabajada y se edifica a través de un camino proselitista. En cambio, los sentimientos emocionales se pueden

57 Así, este autor señala literalmente lo siguiente: «La punición de la conducta del maltrato de animales, por consiguiente, no puede encontrar su explicación ni en la vulneración de un derecho de aquéllos -porque ese derecho no existe-, ni en el «socialmente dominante» sentimiento de rechazo de esa conducta, porque, en este caso, ello justificaría también la prohibición penal de la homosexualidad si en una determinada sociedad «dominase» también socialmente el repudio de esa orientación sexual. (...) En mi opinión, y a diferencia de lo que sucede con la homosexualidad o con otras conductas sexuales libremente consentidas, donde el sentimiento de escándalo que pueden producir en la sociedad -independientemente de lo extendido y arraigado que pueda estar en ésta- no merece protección alguna, porque, como ya he señalado, entra en colisión con los derechos de los actores de la relación sexual constitucionalmente reconocidos en los arts. 10.1, 14 y $16 \mathrm{CE}$, el sentimiento de malestar que origina el «maltrato con ensañamiento e injustificadamente a animales domésticos causándoles la muerte o provocándoles lesiones que produzcan un grave menoscabo físico» (art. $337 \mathrm{CP}$ ) es un sentimiento legítimo sobre el que no puede prevalecer un inexistente derecho del maltratador a desarrollar libremente su personalidad haciendo sufrir a los animales»: Gimbernat ORdeIg, E, en Roland HefENDEHL (ed.) La teoría del bien jurídico... Ob. cit., pp. 17 y 18.

58 Quinta acepción de «moral» en el diccionario de la Real Académica de la Lengua Española.

59 Luis Alonso, «Sentimiento y Emociones, Modelo homeostático de conciencia», en Mente y Cerebro, Revista de Investigación y Ciencia, número 74, 2015, pp. 94 y 95. 
generar cognitivamente de forma espontánea, nacen de forma natural ante determinadas experiencias del ser humano; así, por ejemplo: (i) es natural el sentimiento de dolor al perder un ser querido; (ii) es común el sentimiento de alegría al obtener un ascenso laboral; (iii) es compartido el sentimiento de indignación al contemplar un acto de maltrato físico sobre un niño; o, entre muchos otros, (iv) es normal el sentimiento de rechazo ante casos de maltrato, sádico e injustificado, del reino animal.

Así, a mi juicio, cuando la protección jurídica de sentimientos sea un medio para imponer una determinada moral como fin, esa política legislativa es ilegítima. Pero, cuando la tutela de los sentimientos humanos sea un fin en sí mismo, obtenido mediante la sanción de ciertas conductas humanas, no amparadas en derechos fundamentales, puede, muy excepcionalmente, entenderse justificada ${ }^{60}$.

Ahora bien, dicho todo lo anterior, y a pesar de que los ejemplos de sentimientos de malestar o rechazo elevados a la categoría de bienes jurídicos «penales» en la actualidad son prácticamente inexistentes ${ }^{61}$, considero que, a la luz del principio de última ratio y, el principio de proporcionalidad, debe criticarse que, para solucionar esta cuestión, se acuda al recurso del Derecho penal, despreciándose con ello alternativas de tutela y sanción menos represivas y estigmatizantes, como, quizá, la configuración de una adecuada política social o, como mínimo, la elección del recurso al cuerpo normativo del derecho administrativo sancionador.

De hecho, en el campo de actuación del Derecho administrativo sancionador, la tutela de sentimientos de rechazo o desagrado como interés o bien jurídico protegido es una práctica común. Así, por ejemplo, cuando la Ordenanza municipal de una determinada localidad castiga con multa al que transite desnudo por sus calles, está tutelando el sentimiento de rechazo, ya sea por recato o pudor, ya sea por desagrado, de sus vecinos. Al respecto, de RAÚl ZAFFARONI podemos leer lo siguiente:

${ }^{60}$ De todos modos, actualmente, la doctrina penal, mayoritariamente, rechaza la configuración de los sentimientos como bienes jurídicos, por poner un ejemplo, KNUT AMELUNG utiliza la categoría de los bienes jurídicos aparentes para criticar tal posibilidad AMELUNG, K., El concepto "bien jurídico» en la teoría de la protección penal de bienes jurídicos, en «La teoría del bien jurídico, ¿Fundamentos...op. cit, p. 249.

${ }_{61}$ Ciertamente, los delitos previstos en los artículos 524, 525 y 526 del CP tutelan de algún modo el sentimiento religioso; no obstante, en estos preceptos, a diferencia del delito que castiga el maltrato animal, concurre un bien jurídico vinculado, en cierto modo, a un derecho fundamental: la libertad religiosa y de culto prevista en el artículo 16.1 CE. Qué duda cabe, también, que el delito de injurias previsto en el artículo $208 \mathrm{CP}$ tutela de algún modo sentimientos humanos, no obstante, también aquí el bien jurídico protegido puede vincularse directamente a un derecho fundamental, a saber: el derecho al honor previsto en el artículo 18.1 de la CE. De todos modos, aprovecho este lugar para decir que, en ambos casos (sentimiento religioso e injurias), soy partidario de la derogación de estos tipos penales, asumiendo que sus reclamaciones, a la luz de los principios de proporcionalidad y mínima intervención, pueden ser ventiladas perfectamente en instancias infra penales. 
«no se puede penar a la mujer que usa falda diez centímetros más larga o más corta, porque contraviene la moda o porque desagrada a las comadres del barrio que la atisban detrás de la ventana, pero se puede penar al que sale desnudo a la vía pública porque afecta el sentimiento de recato y reserva sexual de quienes se ven constreñidos a verle desnudo sin quererlo ${ }^{62}$ ».

A mayor abundamiento, antes también he defendido que, entre los bienes jurídicos penales y los bienes jurídicos administrativos media una diferenciación cuantitativa, no cualitativa, lo que comporta que, a mi juicio, ambos ordenamientos punitivos protejan intereses de la misma tipología axiológica, si bien, de distinta intensidad.

Por todo ello, y abordando la pregunta formulada en el título del epígrafe de este cuarto apartado: los sentimientos humanos, a la luz de los principios de proporcionalidad y mínima intervención, no deberían ser intereses legítimamente tutelables por el Derecho penal; no obstante, si concurren los presupuestos señalados en los párrafos precedentes, sí podrían considerarse valores e intereses dignos de protección por medio de las demás instancias del ordenamiento jurídico del Estado.

\section{La discusión sobre los derechos constitucionalmente reconocidos como límites de tutela penal}

Algunos autores han considerado que todo interés postulante a bien jurídico penalmente protegido debe encontrarse, directa o indirectamente, reconocido en algún precepto constitucional ${ }^{63}$. En este contexto, la importancia del catálogo de derechos y valores reconocidos constitucionalmente, a la hora de orientar el correcto camino al legislador, y, con ello, superar el principio de intervención mínima penal, es más que evidente.

62 Raúl Zaffaroni, E: Manual de Derecho Penal. Parte General, Ediar, Buenos Aires. 1999 , p. 53.

63 Por ejemplo, de Franco Bricola puede leerse que el Derecho penal solamente debe utilizarse para contestar «una lesión significativa de un valor constitucionalmente relevante»: Bricola, F, Teoría Generale del Reato, en "Novísimo Digesto Italiano, T XIX», Turín, 1973, p. 15. También pueden encontrarse posiciones similares favorables a la concepción constitucionalista del bien jurídico en: Quintero Olivares, G, (Dir.), Derecho Penal Constitucional, Valencia, Tirant lo Blanch, 2015, p. 84; o, en Silva SÁnchez, J. M, Aproximación al Derecho Penal Contemporáneo, Barcelona, Bosch, 1992, p.274, en cuya obra se señala que la: «exigencia de una consagración constitucional, directa o indirecta, de los bienes penalmente protegibles me parece, pues, plenamente justificada, en la medida en que pone de relieve que una intervención tan intensa sobre el individuo como la pena sólo puede justificarse en caso de afectación de un elemento esencial de la vida en común, al que ha alcanzado el consenso plasmado en la Constitución. La idea de plasmación constitucional debe, pues, ser acogida por añadir un nuevo elemento limitador a las ideas ya reseñadas de afectación al individuo y dañosidad social». 
Ello no significa que no deba reclamarse una valoración diferenciada e independiente del valor o interés analizado, dependiendo de con qué ordenamiento punitivo del Estado se esté trabajando. En este contexto, si estamos discutiendo sobre las exigencias de legitimidad de los bienes jurídicos protegidos en el campo del Derecho administrativo sancionador, el marco constitucional debe concebirse solamente como un marco limitador «negativo», no habilitador "positivo».

Es decir, en las instancias infra penales, los preceptos constitucionales deben configurarse como unos límites que el legislador no puede superar o lesionar ${ }^{64}$, pero, no deben utilizarse como parámetros mínimos habilitantes, sin la concurrencia de los cuales, se proscribiera definitivamente la intervención del ius puniendi. En suma: qué algún interés concreto no se encuentre recogido en la Constitución española no significa que aquél no pueda constituir un objeto legítimo de tutela jurídica por medio del derecho administrativo sancionador ${ }^{65}$.

En este contexto, más arriba he defendido que los intereses susceptibles de poder categorizarse como bienes jurídicos tienen un marcado carácter contingente y son tributarios de las características sociales de cada momento histórico. De hecho, las características y necesidades de tutela de la sociedad española del año 1978 no son exactamente idénticas que las de la ciudadanía actual ni, tampoco, serán idénticas que las de la futura. Ejemplos como el interés (muy minoritario durante la fase constituyente) del respeto al mundo animal (y por consiguiente, la sanción al maltratador) son solo una muestra.

A mayor abundamiento, piénsese que la Constitución Española (del mismo modo que la mayoría de las constituciones de los países nuestro entorno cultural) articula un procedimiento de reforma constitucional cuya complejidad compromete notablemente su éxito ${ }^{66}$.

A diferencia de lo anterior, en el campo del Derecho penal, y con la ayuda de los principios de intervención mínima y proporcionalidad, sí

${ }^{64}$ En este sentido, la Constitución española determina que nadie puede ser discriminado por razón de sexo (artículo 14 de la Constitución española), y, por ello, un legislador retrógrado y moralista (que, desgraciadamente, «de haberlos haylos») no podría castigar, tampoco administrativamente, la homosexualidad.

${ }_{65}$ Por ejemplo, el hecho de que en la Constitución española no aparezca un mandato reconocible en favor de la protección del bienestar de los animales, no obsta para que, en el campo del Derecho administrativo sancionador, puedan castigarse algunas conductas de maltrato hacía aquellos seres.

${ }_{66}$ Como es conocido, el artículo 168 de la Constitución dispone que para modificar el Título preliminar, el Capítulo segundo, Sección primera del Título I, o el Título II: (i) se requerirá la mayoría de dos tercios de cada Cámara, y a la disolución inmediata de las Cortes; (ii) después, las Cámaras elegidas deberán ratificar la decisión y proceder al estudio del nuevo texto constitucional, que deberá ser aprobado por mayoría de dos tercios de ambas Cámaras; y, (iii) finalmente, aprobada la reforma por las Cortes Generales, será sometida a referéndum para su ratificación. 
defiendo que el marco constitucional, cuando identifica y señala el listado de intereses y valores "más importantes» del sistema de convivencia, y, «más fundamentales» para el individuo y la sociedad, delimita, positiva y negativamente, el campo de legitimidad del Derecho penal español ${ }^{67}$.

En concreto, a tenor de una «delimitación constitucional negativa», no pueden castigarse como delito aquellas conductas humanas, libremente consentidas, cuya libertad de realización estuviera expresamente reconocida en la Constitución, a través de su catálogo de derechos y libertades fundamentales ${ }^{68}$.

Asimismo, en el curso de una «delimitación constitucional positiva», solo pueden castigarse como delito aquellas conductas humanas que pudieran lesionar un interés constitucionalmente reconocido.

De todos modos, la delimitación constitucional positiva es una cuestión vinculada al principio de intervención mínima penal y, por ello, solamente puede entenderse como un instrumento que facilita la legítima crítica doctrinal, no como un límite legislativo efectivo. En este sentido, en las páginas iniciales de este artículo, al comentar sucintamente las funciones del bien jurídico, y tratar la cuestión de la función delimitadora del mismo, me he posicionado (a la luz de la actual distribución competencial del Estado, y de las resoluciones del Tribunal Constitucional al respecto), en favor del reconocimiento de una función de crítica legislativa más que de una función realmente limitadora.

Ahora bien, dicho lo anterior, quiero matizar que no considero conveniente exigir que todos los intereses susceptibles de protección penal, sin excepción, deban contar con una consagración constitucional «expresa» que los ampare, siendo suficiente, a mi juicio, aquella vinculación que, como mínimo, sea «tácitamente deducible» del texto constitucional. Por lo tanto, debe utilizarse el marco constitucional como una garantía o límite frente al poder legislativo, pero, no como un programa de política criminal «expresamente» habilitante.

${ }^{67}$ En contra, entre otros, encontraríamos a Alonso Álamo, autora que defiende que «el reconocimiento del principio de exclusiva protección de bienes jurídicos no significa todavía que los bienes jurídicos, en sí, estén contenidos en la Constitución de donde el legislador penal se limitaría a extraerlos. Mucho menos significa que el Estado tenga el deber de incriminar las conductas que atenten contra derechos fundamentales. Significa tan sólo que, de acuerdo con la Constitución, los tipos penales se han de dirigir a proteger bienes jurídicos — deducibles o no de la Constitución- frente a las conductas más intolerables de acuerdo con las exigencias que dimanan de las bases constitucionales del principio de proporcionalidad: AlONSo ÁlAMO, M, Bien jurídico penal: más allá del constitucionalismo de los derechos, en «Estudios Penales y Criminológicos, vol. XXIX, ISSN 1137-7550:61-105», 2009, p. 70.

68 Con el límite, obvio, de que con la materialización de la conducta, constitucionalmente reconocida, no se estuvieran lesionando igualmente los legítimos derechos ajenos. Por ejemplo: la libertad de expresión encuentra uno de sus límites en el derecho al honor ajeno (artículo 20 de la Constitucón española). 
En definitiva, el marco constitucional, en relación al principio del bien jurídico protegido, debe concebirse como un programa legislativo orientativo, con valores o intereses tácitamente deducibles, bastando, por lo tanto, identificaciones indirectas de cuáles valores o intereses deben (o pueden) ser identificados como bienes jurídicos relevantes y, con ello, tutelables penalmente ${ }^{69}$.

Finalmente, con esta identificación "genérica» se permite la vinculación axiológica del bien jurídico penalmente protegido con el contenido del texto constitucional, y, con ello, se facilita la legitimación del recurso punitivo del Derecho penal.

\section{El principio de proporcionalidad en relación al bien jurídico protegido}

Una vez delimitado el interés o valor penalmente tutelado, categorizado, a su vez, como bien jurídico protegido, deberá examinarse la consecuencia jurídica utilizada como respuesta a su lesión (o puesta en peligro) a la luz del principio de proporcionalidad, principio que de forma muy cautelosa y limitada ha sido acogido como juicio de constitucionalidad del tipo penal por parte del Tribunal Constitucional.

De todos modos, de entrada, debe diferenciarse claramente la cuestión de las características que avalan la legitimidad del bien jurídico protegido de la de su protección proporcionada. Esto es: cuando el legislador seleccionada un determinado interés o valor y lo protege penalmente, está habilitando a la doctrina científico-penal para que, con ayuda de los instrumentos de examen señalados en las páginas anteriores, determine su grado su legitimidad material. Ahora bien, una vez delimitado el interés y estudiadas sus características quedará todavía pendiente la posibilidad de analizar la pena concreta del delito, y, con ello, determinar si la consecuencia jurídica específica supera (o no) el juicio de proporcionalidad de los tipos penales.

Un primer examen de proporcionalidad puede llevarse a cabo a través del juicio de necesidad de la pena, es decir: por resultar innecesaria la utilización del Derecho penal para tutelar el bien jurídico penalmente protegido. Así, por ejemplo, en la Sentencia del Tribunal Constitucional

69 Al respecto, HoRmaZABAL MALAREE señala que: «las llamadas teorías constitucionalistas de indudable valor orientativo para la determinación del merecimiento de protección no constituyen propiamente "teorías del bien jurídico» pues no expresan lo que éste es, sino que simplemente buscan en la Constitución política el referente que da fundamento a una política penal coherente con los lineamientos del modelo de Estado que da la propia Constitución»: Hormazabal Malaree, H; Bien jurídico y Estado Social y Democrático de Derecho (el objeto protegido por la norma penal), Barcelona, PPU, 1991. 
55/1996 se señaló que podría atacarse una norma penal cuando: «a la luz del razonamiento lógico, de datos empíricos no controvertidos y del conjunto de sanciones que el mismo legislador ha estimado necesarias para alcanzar fines de protección análogos, resulta evidente la manifiesta suficiencia de un medio alternativo menos restrictivo de derechos para la consecución igualmente eficaz de las finalidades deseadas por el legislador» ${ }^{70}$.

Como se observa, este primer juicio de proporcionalidad intrasistémico permite criticar una norma penal cuando su pena, comparada con las demás alternativas normativas protectoras de bienes jurídicos análogos o, de la misma significancia social, resultara de forma evidente desproporcionada. También, en el mismo esquema, pero en sentido inverso, podría deducirse desproporcionado aquel precepto que castigara con la misma pena que la prevista para conductas típicas cuyo grado de reproche o desvalor sea mucho más intenso ${ }^{71}$.

De todos modos, esta primera limitación legislativa, vinculada inescindiblemente al principio de intervención mínima penal, no discute el tipo de bien jurídico protegido seleccionado, o, sus características de legitimidad concretas. Lo que aquí se hace es analizar la proporcionalidad de las sanciones previstas en el tipo penal, cuestionándolas a partir de su contraste con los eventuales métodos de tutela alternativos ${ }^{72}$. Si estos métodos de tutela alternativos demuestran de forma empírica, en relación al bien jurídico protegido, la misma eficacia preventiva y, además, son instrumentos normativos menos restrictivos de derechos individuales, la desproporcionalidad de la pena se habría evidenciado ${ }^{73}$.

70 STC 55/1996, fundamento jurídico octavo.

71 En términos similares Corcoy Bidasolo, M,: «Expansión del Derecho penal y garantías constitucionales», en Revista de Derechos Fundamentales, N8, 2012, p. 50.

72 O, en palabras de LASCURAín SÁNCHEZ, esta condición «coteja la norma con otras normas hipotéticas: sólo será proporcionada la norma si la protección que depara no puede ser sustituida eficazmente por una norma de menor intensidad coactiva»: LASCURAíN SÁncheZ, J,A: «Bien jurídico y objeto protegible», en Anuario de Derecho Penal y Ciencias Penales, vol. 60, 2007, p. 149.

73 A mi juicio, este examen de proporcionalidad puede poner en riesgo la legitimidad de algunos delitos que tutelan intereses igualmente protegidos mediante el Derecho administrativo sancionador. Por poner un ejemplo: en el campo del derecho urbanístico, en la actualidad, exactamente la misma conducta, la construcción de una edificación no autorizable, levantada en suelo no urbanizable común, es subsumible tanto en las normas administrativas urbanísticas sancionadoras (con sanciones de multa), como, en el delito urbanístico, tipo que comporta una pena de prisión de uno a tres años. De hecho, en relación al delito urbanístico, mediante el Auto del Tribunal Constitucional 395/2004 se resolvió una Cuestión de inconstitucionalidad presentada por la Audiencia Provincial de Ciudad Real, aludiéndose entonces a la posible lesión del principio de proporcionalidad. En aquella ocasión el TC consideró proporcionada y justificada la sanción penal, asumiendo que la pena privativa de libertad del artículo 319.2 del CP no superaba los dos años de prisión, y, por ende, aquella medida era susceptible de suspensión. Ahora bien, mediante la reforma del CP, operada mediante la Ley Orgánica 5/2010, se agravaron las 
Asimismo, el Tribunal Constitucional también se ha pronunciado sobre la proporcionalidad de las normas penales que protegen bienes jurídicos ilegítimos o intereses escasamente relevantes. En concreto, el Tribunal Constitucional ha tenido la ocasión de señalar expresamente que una Ley penal podrá reputarse inconstitucional, por desproporcionada, «si el sacrificio de la libertad que impone la norma persigue la preservación de bienes o intereses, no sólo, por supuesto, constitucionalmente proscritos, sino ya, también, socialmente irrelevantes» ${ }^{74}$. En relación a esta cuestión, MIR PUIG, señala que «un Derecho penal democrático debe ajustar la gravedad de las penas a la trascendencia que para la sociedad tienen los hechos a que se asignan, según el grado de la "nocividad social" del ataque al bien jurídico» ${ }^{75}$.

En este sentido, el concepto de relevancia del bien jurídico como método de limitación del poder legislativo debe interpretarse dentro del marco constitucional vigente. Así, en un Estado social y democrático de derecho, en el que se propugnan como valores superiores de su ordenamiento jurídico la justicia, la libertad, la igualdad y el pluralismo político (artículo 1.1 CE) en el cual, además se proscribe la arbitrariedad de los poderes públicos (artículo 9.3 CE) y, se elevan a la categoría de derechos fundamentales (entre otros) la dignidad y la libertad de la persona (artículos $10.1 \mathrm{CE}$ y $17.1 \mathrm{CE}$ respetivamente), la pena de prisión ni puede responder a un mero capricho del legislador, ni puede utilizarse para tutelar valores contrarios a los postulados constitucionales ni, tampoco, usarse para proteger bienes jurídicos poco relevantes ${ }^{76}$.

En definitiva, en ocasiones la legitimidad de la norma penal, en relación al bien jurídico protegido, podrá encontrarse a través del examen de las penas concretas del delito examinadas a la luz del principio de proporcionalidad penal. En concreto, con este principio podrá determinarse la falta de proporcionalidad de un determinado precepto penal, si, al examinar su pena a la luz del concreto bien jurídico protegido, se concluye que concurre «un desequilibrio patente y excesivo o irrazonable entre la sanción y la finalidad de la norma a partir de las pautas axioló-

penas del delito urbanístico, estableciendo ahora una posible pena de prisión de hasta tres años, la cual, ya no permite el mismo argumento legitimador mostrado por el Tribunal Constitucional.

74 STC 111/1993, fundamento jurídico noveno. También STC 55/1996, fundamento jurídico séptimo.

75 Mir Puig, S: Derecho Penal Parte General, Barcelona, Reppertor, 2016, p. 100.

$76 \mathrm{O}$, en palabras de STERNBERG-LieBen: «la protección estatal de la paz jurídica ni puede pretenderse a cualquier precio ni puede consistir en la prosecución de cualesquiera finalidades que se le ocurra al legislador»: STERNBERG-LieBEN, DetLeV: «Bien jurídico, proporcionalidad y libertad del legislador penal», en La teoría del bien jurídico ¿Fundamento de legitimación del Derecho penal o juego de abalorios dogmático?, Barcelona, Marcial Pons, 2007, p. 108. 
gicas constitucionalmente indiscutibles y de su concreción en la propia actividad legislativa ${ }^{77}$ ».

Por todo ello, en materia penal el sacrificio innecesario y/o excesivo de los derechos individuales, y con ello, la lesión del principio de proporcionalidad, puede producirse esencialmente porque la pena concreta sea notoriamente excesiva en relación a la entidad del valor o interés concretamente protegido, en forma de bien jurídico penalmente tutelado.

Ahora bien, todo lo señalado en este apartado no obsta para que, de todos modos, deba defenderse que el legislador, atendiendo a su especial posición de legitimidad democrática, erigiéndose en el máximo representante de la voluntad popular, tiene que poder configurar los tipos penales con un muy amplio margen de discrecionalidad. Así, lo exige la distribución competencial de poderes del Estado, y, así ha sido reconocido reiteradamente por parte del Tribunal Constitucional. Es más, si se apostara por un sistema fiscalizador absoluto, mediante el cual el Tribunal Constitucional pudiera limitar las facultades del legislador, recortando toda norma contraria a su modelo de política criminal ideal, no solamente se estarían vulnerando las ordinarias competencias del poder legislativo, sino que, incluso, se estaría abandonando un sistema parlamentario constitucional legalista por un eventual modelo tecnócrata constitucionalista, carente éste de la necesaria legitimidad democrática ${ }^{78}$.

Por todo ello, reiterando la idea rectora de este estudio, a mi juicio la función del bien jurídico en el campo de la política criminal es una función de crítica legislativa y no de limitación parlamentaria. Así, el concepto del bien jurídico puede ser un faro que ilumine al camino al legislador: un marco que le ayude a centrar y edificar la mejor política criminal posible en un Estado democrático y social, respetuoso con los derechos fundamentales y libertades públicas. Muy excepcionalmente, si quedase patente y evidente la desproporción de la pena en relación al bien protegido, cabría plantearse la inconstitucionalidad del precepto y, con ello, solicitar la intervención del Tribunal Constitucional para expulsar del ordenamiento jurídico el tipo penal desproporcionado ${ }^{79}$.

77 STC 161/1997, fundamento jurídico decimosegundo.

78 En este sentido, de STERNBERG-LIEBEN puede leerse que: «la política criminal ha de hacerse por el Parlamento democráticamente llamado a ello, y no por medio de decisiones del Tribunal Constitucional, carentes de legitimación constitucional en esta materia»: Sternberg-Lieben, Detlev: «Bien jurídico, proporcionalidad...» Ob cit. p. 124. También SHÜNEMANN señala que el poder judicial no cuenta con la suficiente legitimidad democrática: Shünemann BeRnd: El Derecho penal en el Estado Democrático de Derecho y el irrenunciable nivel de racionalidad de su dogmática, Reus Editorial, Madrid, 2019. pp. 75 y 76.

79 En esta línea, STERnBERG-LiEBen señala que: «El extenso control por el Tribunal Constitucional de las leyes aprobadas por el Parlamento mediante la interpretación extensiva de los derechos fundamentales supondría una dislocación del reparto a tres bandas del poder que efectúa la Constitución, pasándose de la democracia parlamentaria 
De todos modos, como es de pacifico conocimiento, el principio de proporcionalidad no solamente afecta al campo de la política criminal, también sirve de apoyo al poder judicial para llevar a cabo una correcta, equitativa, $\mathrm{y}$, proporcional, individualización de la pena en sede jurisdiccional. Esta cuestión desborda el objeto del presente estudio, no obstante, en lo tocante al bien jurídico, debe señalarse que el juez penal, en ocasiones, tendrá la capacidad de salvar en sede jurisdiccional la lesión del principio de proporcionalidad, si, al momento de la individualización concreta de la pena, modera (dentro de los límites imperantes en el principio de legalidad) la respuesta penológica del Estado considerando, entre otras cuestiones, el valor concreto del bien jurídico lesionado ${ }^{80}$.

\section{Conclusiones}

Como he señalado al inicio de este artículo, desde hace algunos años parte de la doctrina penal discute la relevancia práctica del concepto del bien jurídico penalmente protegido, cuestionando su utilidad, cual abalorio dogmático se tratara.

A diferencia de esta línea doctrinal, en este artículo se ha insistido en la notable importancia práctica del bien jurídico protegido, enumerándose sus dos principales funciones, a saber:

Una función de apoyo a la fase de interpretación de los tipos penales, justificada en el carácter axiológico del principio ${ }^{81}$. Así, el principio del bien jurídico se erige en un recurso de indudable valor hermenéutico, el cual, proporciona al intérprete de la norma un instrumento auxiliar que le ayudará a identificar el sentido, finalidad o espíritu de la norma penal que, en cada caso, deba ser aplicada ${ }^{82}$.

representativa a un Estado de la jurisdicción constitucional.»: STERNBERG-LieBen, DetLev: «Bien jurídico, proporcionalidad...» Ob cit. p. 122.

80 Para ampliarse las cuestiones relativas a la individualización proporcional de la pena puede acudirse, entre muchos otros, a: GARCía ARÁn, M: Los criterios de determinación de la pena en derecho español, Ediciones de la Universidad de Barcelona, 1982; De LA Mata BARRANCo, N,J: La individualización de la pena en los Tribunales de Justicia, Pamplona, Aranzadi, 2008; Demetrio Crespo, E: Prevención general e individualización judicial de la pena, Ediciones Universidad de Salamanca, 1999; FeıJoo SÁNCHEZ, B: «Individualización de la pena y teoría de la pena proporcional al hecho, El debate europeo sobre los modelos de determinación de la pena», en InDret, Revista para el análisis del Derecho 1/2007.

81 En este sentido, LASCURAín SÁNCHEZ señala que: "Correctamente conceptuado, el bien jurídico es capaz de trasmitir sintética y fidedignamente lo principalmente protegido por la norma»: LASCURAín SÁNCHEZ, J,A: «Bien jurídico y objeto protegible», en Anuario de Derecho Penal y Ciencias Penales, vol. 60, 2007, p. 126.

82 Todo ello a la luz del artículo 3 del Código civil, precepto que obliga a interpretar las normas atendiendo fundamentalmente al espíritu y finalidad de aquéllas. A mayor abundamiento, debe recordarse que el objeto de interpretación judicial no debe identificarse con la voluntad del legislador (mens legislatoris) sino el de la Ley misma (mens legis). Así 
Y, también, una función vinculada a la legítima crítica legislativa, justificada a la luz del carácter político-criminal que presente el concepto del bien jurídico penalmente protegido. Es decir, el principio estudiado tiene un fuerte carácter político-criminal que, al menos en un escenario del «deber ser» de una deseable legislación penal racional, proporciona a la doctrina esquemas de legítima crítica legislativa. De hecho, considero que, en las dinámicas legislativas contemporáneas, expansivas del Derecho penal, el principio del bien jurídico se ha consagrado como un instrumento de crítica legislativa fundamental, ya que, con su concurso, la doctrina jurídico-penal puede (y debe) criticar todas aquellas decisiones político-legislativas que apuesten por tipos penales ilegítimos.

Pues bien, a mi juicio, a todos y a cada uno de los delitos del Código penal puede reconocérseles algún interés o valor tutelado que, en última instancia, pueda considerarse su bien jurídico protegido. En este sentido, debe tenerse presente que el concepto del bien jurídico protegido es un concepto de naturaleza dogmática, cuya existencia se encuentra en el plano de la reflexión intelectual axiológica, y, por ello, incluso en los casos más extremos de dificultad interpretativa, siempre cabrá ofrecerse algún tipo de ocurrencia teleológica que identifique el interés o valor protegido en el delito examinado.

Ahora bien, una vez identificado el bien jurídico, deberá analizarse su grado de legitimidad material. En este contexto, más arriba he dicho que, de lege lata, los bienes jurídicos, al menos formalmente, son aquellos intereses o valores «vigentemente» tutelados por el ordenamiento jurídico del Estado. En cambio, y a diferencia de lo anterior, de lege ferenda (o estructura de derecho deseable) debería defenderse que solamente pueden identificarse como bienes jurídicos legítimos aquellos intereses o valores «legítimamente» tutelados por el ordenamiento.

En este contexto, inescindiblemente, para poder llevar a cabo el examen de legitimidad del tipo penal, a la luz del principio del bien jurídico, antes deberá identificarse qué tipo de intereses concretos pueden ser considerados bienes jurídicos legítimos o, qué características deben exigirse para que determinados valores pueda ser estimados objetos dignos de tutela penal. Por ende, en la búsqueda y determinación de la legitimidad material del bien jurídico, la doctrina jurídico-penal debe seguir esforzándose por identificar, despreciar y criticar, todo aquél bien jurídico ilegítimo, apoyándose para ello, entre otras, en las siguientes condiciones de legitimidad:

De entrada, actualmente está totalmente aceptada la idea de que el Estado no debe utilizar el Derecho penal para intentar imponer un deter-

se expresa, por ejemplo: Luzón Cuesta, J.M: Compendio de Derecho Penal, Parte General, Madrid, Dykinson, 2011. 
minado esquema moral a sus ciudadanos. En nuestro país, afortunadamente, el Estado totalitario está felizmente superado.

Asimismo, puede decirse que una norma penal será ilegítima si en la base de justificación de la misma no puede hallarse ningún interés cuya protección sirva para garantizar el libre desarrollo de la persona en sociedad.

Igualmente, el principio del bien jurídico no puede utilizarse para lesionar injustificadamente derechos fundamentales constitucionalmente reconocidos; pero, sí cabe esgrimirlo para proteger intereses o valores que no tengan un expreso mandato de tutela constitucional, siendo bastante una referencia indirecta o, al menos, tácitamente deducible de los mismos en nuestra Carta Magna.

También, no creo que deban aceptarse las críticas lanzadas contra los bienes jurídicos colectivos por parte de algunas corrientes doctrinales. Estas críticas, en ocasiones, se acercan peligrosamente a concepciones clasistas del ordenamiento jurídico por las que se asume que los intereses de la clase propietaria deben contar con la máxima protección del ordenamiento jurídico, pero, que los intereses de la comunidad en su conjunto deben despreciarse y relegarse sin excepción a instancias menos tuitivas.

Resumiendo: considero que, formalmente, un bien jurídico es aquel interés o valor tutelado por medio del Derecho. A su vez, cuando el instrumento de tutela elegido sea el Derecho penal estaremos, formalmente, ante un bien jurídico penalmente protegido. Pues bien, una vez identificado el valor o interés formalmente protegido, la doctrina, con ayuda de los instrumentos de valoración dogmática, podrá determinar el grado de legitimidad material del bien jurídico protegido.

En esta línea de pensamiento doctrinal, por ejemplo, de LASCUARín SÁNCHEZ podemos leer que «no cabe legitimación democrática de los preceptos sancionadores puramente caprichosos, ni de aquellos que se limitan a proteger una determinada concepción moral de la sociedad, ni los que protegen un objeto incompatible con un derecho o libertad fundamental, ni los que sancionan el ejercicio adecuado de los mismos sin justificación en la tutela de un derecho o libertad prevalente» ${ }^{83}$.

En definitiva, entiendo que solamente debe elevarse a la categoría de bien jurídico legítimamente protegido aquel interés o valor cuyas características materiales se acomoden pacíficamente dentro del sistema de valores y derechos constitucionales de nuestro Estado social y democrático de Derecho. Por ello, podrían considerarse «bienes jurídicos legítimos» todos aquellos intereses o valores, individuales o colectivos, cuya

83 Lascuraín SÁnchez, J,A: «Bien jurídico y legitimidad de la intervención penal», en Revista Chilena de Derecho, vol. 22, N², 1995, p. 262. 
tutela jurídica sirviera para favorecer el libre desarrollo de la persona en sociedad, no consistentes en meras cuestiones morales, siempre que el plan vital de aquélla no tuviera por objeto, o precisara como medio, la lesión de los derechos subjetivos de sus semejantes. Igualmente, y, como complemento necesario de lo antecedente, una vez decididos los bienes que deben ser jurídicamente protegidos, debería hacerse una ulterior selección, a saber: de cuantos intereses y valores reconocidos, elegir aquéllos más importantes y fundamentales para el individuo y la sociedad, y, una vez identificados, elevarlos a la categoría de bienes jurídicos «penalmente» protegidos para que, con ello, fueran confiados al recurso tutelar más intenso y coactivo del Estado.

Finalmente, una vez categorizado el bien jurídico penalmente protegido, y deducidas sus principales características de legitimidad, quedaría pendiente el juicio que podría llevarse a cabo a la luz del principio de proporcionalidad. En este contexto, debe recordarse que el Tribunal Constitucional ha resuelto que las normas penales podrán ser contrarias al principio de proporcionalidad (y, con ello, susceptibles de ser declaradas inconstitucionales) si protegen bienes jurídicos poco relevantes o constitucionalmente proscritos, o, cuando se evidencie, a la luz del bien jurídico, un desequilibrio patente y excesivo, entre la sanción penal seleccionada y la finalidad de la norma punitiva.

Ahora bien, en este artículo también he querido señalar que el juicio de constitucionalidad del precepto penal, a la luz del principio de proporcionalidad, debe llevarse a cabo de forma muy cautelosa y limitada, solamente justificada cuando la desproporción del interés protegido, con la pena vinculada, sea del todo flagrante y evidente. Lo contrario comportaría el peligro de propiciar (al menos de facto) un cambio en el modelo de fuentes legislativas: del actual sistema democrático parlamentario, a un modelo tecnócrata constitucionalista, huérfano de la necesaria legitimidad democrática.

\section{Bibliografía:}

ACALE Sánchez, M: Los nuevos delitos sobre la ordenación del territorio y el urbanismo, $1^{\text {a }}$ edición, Barcelona, Bosch, 2011.

Alonso Álamo, M: Bien jurídico penal: más allá del constitucionalismo de los derechos, en «Estudios Penales y Criminológicos, vol XXIX, ISSN 1137-7550:61-105», 2009.

Alonso Álamo, M: Fundamentación pre-positiva de los bienes jurídicospenales y Derecho penal mínimo de los Derechos Humanos, en «Iustel, Revista General de Derecho Penal - 15», 2011.

Amelung, K., El concepto «bien jurídico» en la teoría de la protección penal de bienes jurídicos, en «La teoría del bien jurídico, ¿Fundamentos de 
legitimación penal o juego de abalorios dogmático? ", Marcial Pons, Madrid, 2007.

ANDREW VON HIRSCH: «El concepto de bien jurídico protegido y el principio del daño", en La teoría del bien jurídico ¿Fundamentos de legitimación del Derecho penal o juego de abalorios dogmático? Barcelona, Marcial Pons, 2007.

Berdugo Gómez de la Torre, I: Viejo y nuevo Derecho penal. Principios y desafíos del Derecho penal de hoy, Iustel, Madrid, 2012.

Bricola, F, Teoría Generale del Reato, en "Novísimo Digesto Italiano, T XIX», Turín, 1973.

Corcoy Bidasolo, M,: «Expansión del Derecho penal y garantías constitucionales», en Revista de Derechos Fundamentales, No 8, 2012.

CORTINA ORTS, A: Las fronteras de la persona, El valor de los animales, la dignidad de los humanos, editorial Taurus, Madrid, 2009.

De la Mata Barranco, N,J: La individualización de la pena en los Tribunales de Justicia, Pamplona, Aranzadi, 2008.

Demetrio CRespo, E: Prevención general e individualización judicial de la pena, Ediciones Universidad de Salamanca, 1999.

Diez Ripollés, J,L: La racionalidad de las leyes penales, editorial Trotta, Madrid, 2003.

Diez Ripollés, J,L: Delitos y penas en España, editorial Catarata, Madrid, 2015.

FeIJoo SÁNCHeZ, B: «Individualización de la pena y teoría de la pena proporcional al hecho, El debate europeo sobre los modelos de determinación de la pena», en InDret, Revista para el análisis del Derecho 1/2007.

FERRAJOLI, L, Derecho y razón. Teoría del garantísmo penal, $10^{\mathrm{a}}$ edición (segunda reimpresión), Madrid, Trotta, 2016.

GARCía ARÁN, M: Los criterios de determinación de la pena en derecho español, Ediciones de la Universidad de Barcelona, 1982.

García Arán, M, y Botella Corral, J, (Directores): Malas noticias. Medios de comunicación, política criminal y garantías penales en España, Valencia, Tirant lo Blanch, 2009.

Gimbernat Ordeig, E: «Presentación», en Roland Hefendehl (ed.), La teoría del bien jurídico, ¿Fundamento de legitimación del Derecho penal o juego de abalorios dogmático?, Madrid, Marcial Pons, 2007.

HASSEMER, W: «¿Puede haber delitos que no afecten a un bien jurídico penal?» en La teoría del bien jurídico ¿Fundamentos de legitimación del Derecho penal o juego de abalorios dogmático? Barcelona, Marcial Pons, 2007. 
Hormazabal Malaree, H: Bien jurídico y Estado Social y Democrático de Derecho (el objeto protegido por la norma penal), Barcelona, PPU, 1991.

Lascuraín SÁnchez, J,A: «Bien jurídico y legitimidad de la intervención penal», en Revista Chilena de Derecho, vol. 22, N² 2, 1995, pp. 251 a 264.

Lascuraín Sánchez, J,A: «Bien jurídico y objeto protegible», en Anuario de Derecho Penal y Ciencias Penales, vol. 60, 2007, pp. 119 a 163.

LuIS ALONSO: «Sentimiento y Emociones, Modelo homeostático de conciencia», en Mente y Cerebro, Revista de Investigación y Ciencia, número 74, 2015.

Luzón Cuesta, J.M: Compendio de Derecho Penal, Parte General, Madrid, Dykinson, 2011.

LuZÓn PeÑa, D.M, y Mir Puig, S, (coordinadores): Causas de Justificación y de Atipicidad en Derecho Penal, Editorial Aranzadi, Pamplona, 1995.

Mir Puig, S: Derecho Penal Parte General, Barcelona, Reppertor, 2016.

Corcoy Bidasolo, M,: «Expansión del Derecho penal y garantías constitucionales», en Revista de Derechos Fundamentales, No8, 2012, pp. $45-76$.

Muñoz Conde, F., Introducción al Derecho penal, Barcelona, Editorial Bosch, primera edición, 1975.

Muñoz Conde, F., García Arán, M: Derecho Penal Parte General, Valencia, Tirant lo Blanch, 2015.

NAVARRo CARDOSO, F: Infracción administrativa y delito: Límites a la intervención del Derecho penal, Madrid, Colex, 2001.

Nieto García, A: Derecho Administrativo Sancionador, Madrid, Tecnos, 2012.

Portillo Contreras, G: «La protección del derecho al medio ambiente y los derechos económicos-sociales en un periodo de crisis del Derecho y del Estado de Derecho» en Quintero Olivares, G, y, Morales Prats, F (Coords.): Estudios de Derecho ambiental, Valencia, Tirant Lo Blanch, 2008.

Quintero Olivares, G: La Justicia Penal en España, Pamplona, Aranzadi, 1998.

Quintero Olivares, G (Dir.):, Derecho Penal Constitucional, Valencia, Tirant lo Blanch, 2015.

Raúl Zaffaroni, E: Manual de Derecho Penal. Parte General, Ediar, Buenos Aires. 1999.

Roxin, Claus: «¿Es la protección de bienes jurídicos una finalidad del Derecho penal?», en Roland Hefendehl (ed.) La teoría del bien jurídico, 
¿Fundamentos de legitimación del derecho penal o juego de abalorios dogmático?, Madrid, Marcial Pons, 2007.

Roxin Claus: El concepto de bien jurídico como instrumento de crítica legislativa sometido a examen, Revista Electrónica de Ciencia Penal y Criminología, ISSN 1695-0194, 2013.

Roxin Claus: La teoría del Delito en la discusión actual, Tomo II, Grijley, Lima, 2015.

Silva SÁnchez: J. M, Aproximación al Derecho Penal Contemporáneo, Barcelona, Bosch, 1992.

SHÜNEMANN BERND: «El principio de protección de bienes jurídicos como puno de fuga de los límites constitucionales de los tipos penales y de su interpretación», en La teoría del bien jurídico ¿Fundamento de legitimación del Derecho penal o juego de abalorios dogmático?, Barcelona, Marcial Pons, 2007.

ShÜnemann Bernd: El Derecho penal en el Estado Democrático de Derecho y el irrenunciable nivel de racionalidad de su dogmática, Reus Editorial, Madrid, 2019.

SteRnBerg-Lieben, Detlev: «Bien jurídico, proporcionalidad y libertad del legislador penal», en La teoría del bien jurídico ¿Fundamento de legitimación del Derecho penal o juego de abalorios dogmático?, Barcelona, Marcial Pons, 2007.

StUart Mill, John: On Liberty, 1859.

Von Liszt, F: Tratado de Derecho Penal, Tomo II, traducido por Jiménez de Asúa, Madrid, 1916. 